Biogeosciences, 10, 851-869, 2013

www.biogeosciences.net/10/851/2013/

doi:10.5194/bg-10-851-2013

(C) Author(s) 2013. CC Attribution 3.0 License.

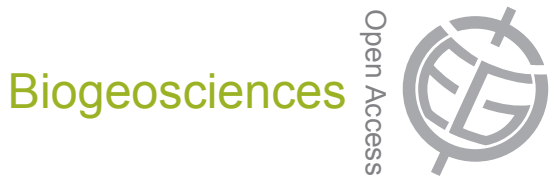

\title{
The Australian terrestrial carbon budget
}

\author{
V. Haverd ${ }^{1}$, M. R. Raupach ${ }^{1}$, P. R. Briggs ${ }^{1}$, J. G. Canadell. ${ }^{1}$, S. J. Davis ${ }^{2}$, R. M. Law $^{3}$, C. P. Meyer ${ }^{3}$, G. P. Peters ${ }^{4}$, \\ C. Pickett-Heaps ${ }^{1}$, and B. Sherman ${ }^{5}$ \\ ${ }^{1}$ CSIRO Marine and Atmospheric Research, P.O. Box 3023, Canberra ACT 2601, Australia \\ ${ }^{2}$ University of California, Irvine, Dept. of Earth System Science, CA, USA \\ ${ }^{3}$ CSIRO Marine and Atmospheric Research, PB1, Aspendale, Victoria 3195, Australia \\ ${ }^{4}$ Center for International Climate and Environmental Research - Oslo (CICERO), P. B. 1129 Blindern, 0318 Oslo, Norway \\ ${ }^{5}$ CSIRO Land and Water, P.O. Box 1666, Canberra ACT 2600, Australia
}

Correspondence to: V. Haverd (vanessa.haverd@csiro.au)

Received: 31 July 2012 - Published in Biogeosciences Discuss.: 12 September 2012

Revised: 14 December 2012 - Accepted: 26 December 2012 - Published: 7 February 2013

\begin{abstract}
This paper reports a study of the full carbon (C$\mathrm{CO}_{2}$ ) budget of the Australian continent, focussing on 19902011 in the context of estimates over two centuries. The work is a contribution to the RECCAP (REgional Carbon Cycle Assessment and Processes) project, as one of numerous regional studies. In constructing the budget, we estimate the following component carbon fluxes: net primary production (NPP); net ecosystem production (NEP); fire; land use change (LUC); riverine export; dust export; harvest (wood, crop and livestock) and fossil fuel emissions (both territorial and non-territorial).
\end{abstract}

Major biospheric fluxes were derived using BIOS2 (Haverd et al., 2012), a fine-spatial-resolution $\left(0.05^{\circ}\right)$ offline modelling environment in which predictions of CABLE (Wang et al., 2011), a sophisticated land surface model with carbon cycle, are constrained by multiple observation types.

The mean NEP reveals that climate variability and rising $\mathrm{CO}_{2}$ contributed $12 \pm 24$ ( $1 \sigma$ error on mean) and $68 \pm 15 \mathrm{TgC} \mathrm{yr}^{-1}$, respectively. However these gains were partially offset by fire and LUC (along with other minor fluxes), which caused net losses of $26 \pm 4 \mathrm{TgC} \mathrm{yr}^{-1}$ and $18 \pm 7 \mathrm{TgC} \mathrm{yr}^{-1}$, respectively. The resultant net biome production (NBP) is $36 \pm 29 \mathrm{TgC} \mathrm{yr}^{-1}$, in which the largest contributions to uncertainty are NEP, fire and LUC. This NBP offset fossil fuel emissions ( $95 \pm 6 \mathrm{TgC} \mathrm{yr}^{-1}$ ) by $38 \pm 30 \%$. The interannual variability (IAV) in the Australian carbon budget exceeds Australia's total carbon emissions by fossil fuel combustion and is dominated by IAV in NEP. Territorial fossil fuel emissions are significantly smaller than the rapidly growing fossil fuel exports: in 2009-2010, Australia exported 2.5 times more carbon in fossil fuels than it emitted by burning fossil fuels.

\section{Introduction}

Full carbon budgets for land regions are significant for several reasons: they provide insights into terrestrial carbon cycle dynamics, including processes contributing to the net trend and variability in the terrestrial carbon sink; they place anthropogenic carbon and greenhouse gas inventories in a broader context; and they indicate how anthropogenic inventories change spatially across regions and temporally in response to climate variability and changes in land use and land management. This paper reports a study of the full carbon budget of the Australian continent, focussing on 1990-2011 in the context of estimates over two centuries. The work is a contribution to the RECCAP (REgional Carbon Cycle Assessment and Processes) project (Canadell et al., 2011), as one of numerous regional studies being synthesised in RECCAP.

A carbon budget for a land region can be expressed by equating the change in territorial storage of carbon $\mathrm{C}_{\mathrm{T}}$ per unit time $t$ with the net flux of carbon into the land surface:

$$
\begin{aligned}
& -\mathrm{dC}_{\mathrm{T}} / \mathrm{d} t=-\mathrm{dC}_{\mathrm{B}} / \mathrm{d} t-\mathrm{dC}_{F F} / \mathrm{d} t-\mathrm{dC}_{\mathrm{HWP}} / \mathrm{d} t \\
& \quad=\left(F_{\mathrm{NPP}}+F_{\mathrm{RH}}+F_{\text {Fire }}+F_{\mathrm{LUC}}+F_{\text {Transport }}\right. \\
& \left.\quad+F_{\text {Harvest }}\right)+\left(F_{\mathrm{FF}}+F_{\mathrm{FF}, \text { Export }}\right)-\mathrm{dC}_{\mathrm{HWP}} / \mathrm{d} t
\end{aligned}
$$

Here, $C_{\mathrm{B}}, \mathrm{C}_{\mathrm{FF}}$ and $\mathrm{C}_{\mathrm{HWP}}$ are $\mathrm{C}$ stocks in the biospheric, fossil fuel and harvested wood product (HWP) pools, respectively. 
Changes in other $\mathrm{C}$ pools (e.g. biological products other than HWP) are considered negligible. The sign convention for $F$ is that a positive flux is directed away from the land surface. (However note also the following hereafter: (i) positive "productivities" denoted e.g. NPP (net primary production), NEP (net ecosystem production), and NBP (net biome production); in the absence of the main symbol $F$ are by definition uptake by the land; (ii) positive "exports" and "emissions" are by definition fluxes away from the land surface.) Flux subscripts denote contributions to the net flux from NPP, heterotrophic respiration $(\mathrm{RH})$, fire, land use change (LUC), transport by rivers and dust, harvest, fossil fuel emissions (FF), and FF export. It is assumed that, in all gaseous fluxes, $\mathrm{C}$ is present as $\mathrm{C}$ in $\mathrm{CO}_{2}$, and that the ultimate fate of $\mathrm{C}$ in the lateral fluxes (transport, harvest, exported $\mathrm{FF}$ ) is $\mathrm{C}$ in $\mathrm{CO}_{2}$. (Hereafter $\mathrm{C}$ in $\mathrm{CO}_{2}$ will be abbreviated as $\mathrm{C}$.) Terms in Eq. (1) can also be used to construct the net landto-atmosphere $\mathrm{C}$ flux:

$$
\begin{aligned}
F_{\mathrm{LAE}} & =F_{\mathrm{NPP}}+F_{\mathrm{RH}}+F_{\mathrm{Fire}}+F_{\mathrm{LUC}}+F_{\mathrm{FF}} \\
& +F_{\text {Harvest }}^{\text {Consump }}-\mathrm{dC} \mathrm{CWP}_{\mathrm{HWP}} / \mathrm{d} t,
\end{aligned}
$$

where LAE denotes land-atmosphere exchange and

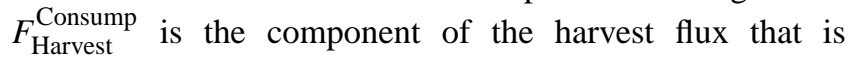
consumed within the land region. The portion of the harvest that is consumed but does not decompose is accounted for by the change in stored HWP. The total change in atmospheric $\mathrm{C}$ storage attributable to loss of $\mathrm{C}$ from the land is given by $-\mathrm{dC}_{\mathrm{T}} / \mathrm{d} t$ (Eq. 1 ), and is the sum of $F_{\mathrm{LAE}}$ and non-territorial (NT) emissions resulting from lateral fluxes (i.e. transport fluxes, and the export of harvest and FF). As such, a bottom-up estimate of $\mathrm{dC}_{\mathrm{T}} / \mathrm{d} t$ formed by estimating the component fluxes provides an independent test of results from "top-down" atmospheric inversion approaches (Canadell et al., 2011).

The aim of this work is to construct a full carbon budget for the period 1990-2011 by combining estimates of the fluxes in Eq. (1). Methods for estimating the flux components are detailed in Sect. 2, and the budget is summarised in Sect. 3. Details of the component fluxes are presented in Sect. 4. In Sect. 5 atmospheric inversion results for Australia are discussed.

\section{Methods and datasets}

Net primary production and net ecosystem production were obtained using a regional biospheric modelling environment (BIOS2), subject to constraint by multiple observation sets (including eddy flux data and carbon pool data), as described in Sect. 2.1 below. We chose to use BIOS2 in preference to multiple estimates of NPP and NEP from global ecosystem models participating in the carbon cycle model intercomparison project (TRENDY) (Sitch and Friedlingstein, 2011). The reason for this is that these global models exhibit variability in Australian continental NPP estimates $\left(2.2 \mathrm{PgCy}^{-1}\right.$ (range) and $\left.0.8 \mathrm{PgCy}^{-1}(1 \sigma)\right)$, which is much higher than the uncertainty $\left(0.2 \mathrm{PgCy}^{-1}(1 \sigma)\right)$ in the regionally constrained BIOS2 estimates (Haverd et al., 2012).

Most other components of the carbon budget were obtained independently as described in Sects. 2.2-2.6, with two exceptions. First, the heterotrophic respiration, which is derived primarily from BIOS2, is corrected for the influences of fire, transport (by river and dust) and harvest (Sect. 2.1). Second, the net fire emissions from non-clearing fires were estimated using a BIOS2 simulation with prescribed gross fire emissions (Sect. 2.2.2).

\subsection{Net primary production, net ecosystem production and heterotophic respiration}

NPP and NEP components were derived using BIOS2 (Haverd et al., 2012), constrained by multiple observation types, and forced using remotely sensed vegetation cover. BIOS2 is a fine-spatial-resolution $\left(0.05^{\circ}\right)$ offline modelling environment built on capability developed for the Australian Water Availability Project (King et al., 2009; Raupach et al., 2009). It includes a modification of the CABLE land surface scheme (Wang et al., 2011) incorporating the SLI soil model (Haverd and Cuntz, 2010) and the CASA-CNP biogeochemical model (Wang et al., 2010). BIOS2 parameters are constrained and predictions are evaluated using multiple observation sets from across the Australian continent, including streamflow from 416 gauged catchments, eddy flux data $\left(\mathrm{CO}_{2}\right.$ and $\left.\mathrm{H}_{2} \mathrm{O}\right)$ from $12 \mathrm{OzFlux}$ sites, litterfall data, and data on soil, litter and biomass carbon pools (Haverd et al., 2012).

CABLE consists of five components (Wang et al., 2011): (1) the radiation module describes direct and diffuse radiation transfer and absorption by sunlit and shaded leaves; (2) the canopy micrometeorology module describes the surface roughness length, zero-plane displacement height, and aerodynamic conductance from the reference height to the air within canopy or to the soil surface; (3) the canopy module includes the coupled energy balance, transpiration, stomatal conductance and photosynthesis of sunlit and shaded leaves; (4) the soil module describes heat and water fluxes within soil and snow and at their respective surfaces; and (5) the ecosystem carbon module accounts for the respiration of stem, root and soil organic carbon decomposition. In BIOS2, the default CABLE v1.4 soil and carbon modules were replaced respectively by the SLI soil model (Haverd and Cuntz, 2010) and the CASA-CNP biogeochemical model (Wang et al., 2010). Modifications to CABLE, SLI and CASA-CNP for use in BIOS2 are detailed in Haverd et al. (2012).

Nitrogen and phosphorous cycles in CASA-CNP were disabled, and land management was not considered explicitly. However BIOS2 is driven by remotely sensed vegetation cover and parameters and uncertainties were estimated using multiple observation types spanning the entire bioclimatic space, including managed lands. These two factors mitigate against the exclusion of potentially important processes. 
Moreover, model structural errors incurred by process omission are incorporated in the model-observation residuals, which are propagated through to uncertainties in model predictions (Haverd et al., 2012).

In this work we extended BIOS2 simulations back in time to 1799 , to assess the effects of changing climate and atmospheric $\mathrm{CO}_{2}$ on NPP and NEP. CASA-CNP carbon pools were initialised by spinning the model 200 times over a $39 \mathrm{yr}$ period using NPP generated with atmospheric $\mathrm{CO}_{2}$ fixed at the pre-industrial value of $280 \mathrm{ppm}$, and 1911-1949 meteorology, corresponding to the earliest available rainfall and temperature data from the Bureau of Meteorology's Australian Water Availability Project dataset (BoM AWAP) (Grant et al., 2008; Jones et al., 2009). Following spin-up, the 1799-2011 simulation was performed using actual deseasonalised atmospheric $\mathrm{CO}_{2}$ (from the Law Dome ice core prior to 1959 (MacFarling Meure et al., 2006), and from global in situ observations from 1959 onward (Keeling et al., 2001) with repeated 1911-1949 meteorology prior to 1911 and actual meteorology thereafter.

Vegetation cover was prescribed using PAR (fraction photosynthetic absorbed radiation) estimates obtained from the AVHRR record (1990-2006), with an annual climatology being used outside of the period of data availability. Total fPAR was partitioned into persistent (mainly woody) and recurrent (mainly grassy) vegetation components, following the methodology of Donohue et al. (2009) and Lu et al. (2003). Leaf area index (LAI) for woody and grassy components was estimated from the fPAR components by Beer's law (e.g. Houldcroft et al., 2009). Grassy LAI was partitioned between $\mathrm{C}_{3}$ and $\mathrm{C}_{4}$ components according to the proportion of all grass species that are $\mathrm{C}_{4}$ species, as estimated by Hattersley (1983).

Uncertainties in BIOS2 predictions (all uncertainties hereafter expressed as $1 \sigma$ ), due to parameter uncertainty and uncertainty in forcing data, were estimated separately and combined in quadrature to give total uncertainty, as described by Haverd et al. (2012). To obtain uncertainties in model predictions associated with parameter uncertainties in a parameter set $p$, the parameter covariance matrix $\mathbf{C}$ was projected onto the variance in the prediction $Z$ :

$\sigma_{Z}^{2}=\left(\frac{\overline{\partial Z}}{\partial p}\right)^{T} \mathbf{C} \frac{\overline{\partial Z}}{\partial p}$

where $\overline{\partial Z / \partial p}$ is the vector of sensitivities of a prediction $Z$ to the elements of $p$. Uncertainties in model predictions associated with forcing uncertainties were estimated as the absolute change in prediction associated with perturbations to forcing inputs. NEP uncertainty estimates also include the uncertainty due to an assumed $20 \%$ uncertainty in the partial derivative of NPP with respect to atmospheric $\mathrm{CO}_{2}$ concentration.

We define net ecosystem production as net primary production (NPP) minus the heterotrophic respiration flux that would occur without the influences of fire, transport (by river and dust) and harvest, $F_{\text {RH,-F-T-H }}$ (Here subscripts -F, -T, $\mathrm{H}$ denote the absence of fire, harvest and transport.) Section 2.2 describes the estimation of $F_{\mathrm{RH},-\mathrm{F}-\mathrm{T}-\mathrm{H}}$, i.e. $F_{\mathrm{RH}}$ under a regime of fire. The effect of harvest and transport on $F_{\mathrm{RH}}$ is treated more simply: we assume $F_{\mathrm{RH}}$ is discounted by $100 \%$ of the exported flux, because the $\mathrm{C}$ in these fluxes is removed and cannot be respired.

\subsection{Fire}

\subsubsection{Gross fire emissions}

Gross monthly fire emissions were extracted from the GFED3 database (van der Werf et al., 2010) for the 19972009 period. These emissions are determined using the algorithm of Sieler and Crutzen (1980), with burnt area determined from the MODIS burned area product from 2002 to 2009 and from AVHRR for the period 1997-2002 (Giglio et al., 2010), fuel loads calculated using the CASA terrestrial biosphere model (Randerson et al., 1997) and combustion parameters sourced from the global literature. These were compared with independent estimates derived using the $2004 \mathrm{Na}-$ tional Greenhouse Gas Inventory Methodology (Australian Greenhouse Office, 2006; Meyer, 2004). This methodology also implements the algorithm of Sieler and Crutzen (1980). However the data are entirely independent of GFED. Burnt area in the tropical savanna and arid rangelands is estimated from AVHRR $1 \mathrm{~km}$ imagery (Craig et al., 2002) while, for the forests area, fire area estimates are sourced from fire agency statistics. In all regions fuel loads and combustion parameters are sourced from field measurements. The NGGI (National Greenhouse Gas Inventory) methodology is implemented regionally, by state (administrative unit), while GFED3 is spatially explicit at $0.5 \mathrm{deg}$ resolution.

Uncertainty $(1 \sigma)$ in continental gross fire emissions was estimated as the difference between the NGGI and GFED3, each averaged over the period (1997-2009) for which both products exist.

\subsubsection{Net fire emissions}

We define net fire emissions (of $\mathrm{CO}_{2}-\mathrm{C}$ ) as the sum of contributions from clearing fires (i.e. fires associated with conversion of forest to cropland or grassland) and non-clearing fires. Together gross emissions from these two categories of fire sum to the total gross fire emissions (detailed above and denoted by the "Fire" arrow in Fig. 1). Net emissions from clearing fires are assumed equal to the gross emissions from these fires. In contrast, net emissions from non-clearing fires are estimated as the gross non-clearing fire emissions minus the reduction in $F_{\mathrm{RH}}$ incurred by non-clearing fires (relative to a no-fire scenario). For non-clearing fires, NPP simulated using BIOS2 in the absence of fire was assumed applicable under a recurring fire regime, because most Australian 


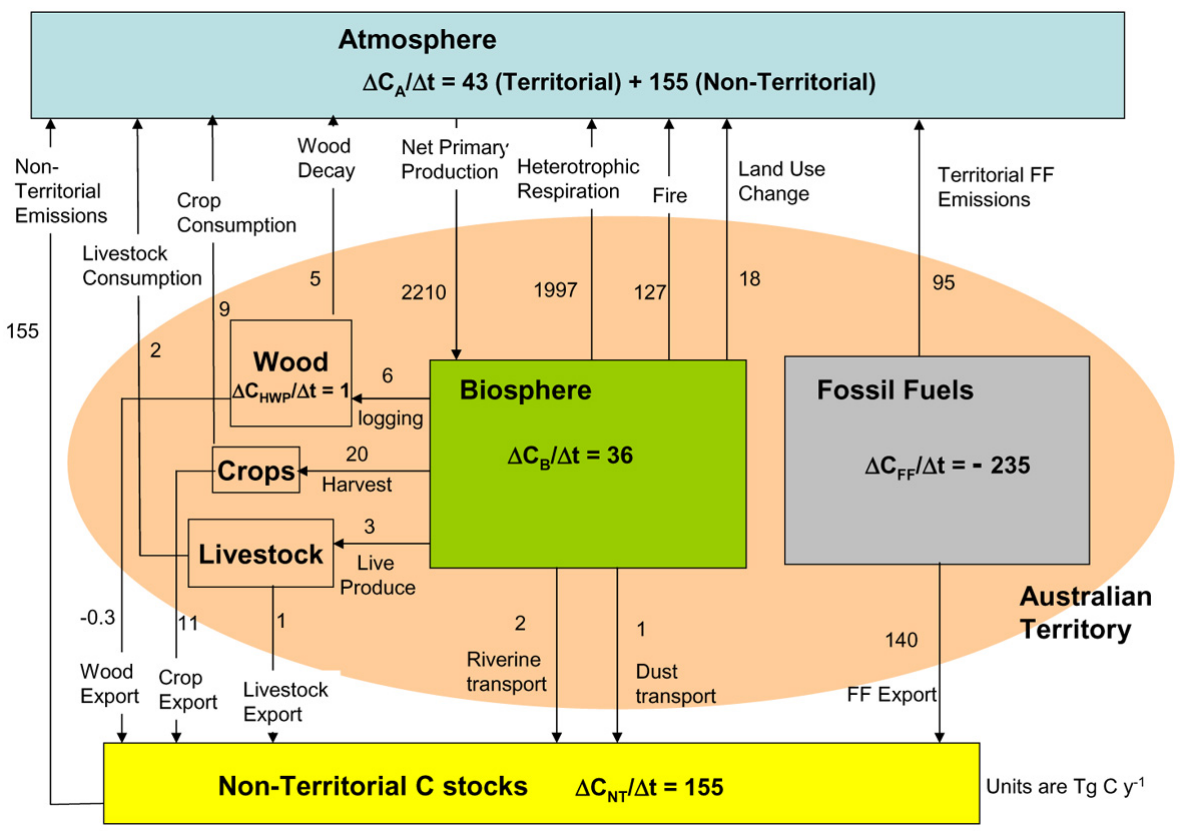

Fig. 1. Summary of the Australian territorial carbon budget, 1990-2011.

landscapes are resilient, with regrowth commencing after the first post-fire rainfall (Graetz, 2002).

For the purpose of estimating net fire emissions, clearing

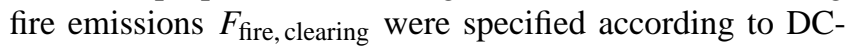
CEE (2012) and subtracted from the gross fire emissions

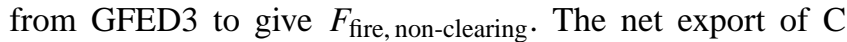
from the biosphere due to non-clearing fires was evaluated as

$$
\begin{aligned}
& F_{\text {fire, non-clearing }}^{\text {net }}=F_{\text {fire, non-clearing }}-F_{\mathrm{RH},-\mathrm{F}-\mathrm{T}-\mathrm{H}}+F_{\mathrm{RH}, \mathrm{T}-\mathrm{H}} \\
& =F_{\text {fire, non-clearing }}\left(1-\frac{F_{\mathrm{RH},-\mathrm{F}-\mathrm{T}-\mathrm{H}}-F_{\mathrm{RH},-\mathrm{T}-\mathrm{H}}}{F_{\text {fire, non-clearing }}}\right)
\end{aligned}
$$

Heterotrophic respiration under a recurring fire regime (but without account for transport by rivers and dust or harvest), $F_{\mathrm{RH},-\mathrm{T}-\mathrm{H}}$, was estimated using a modification of the BIOS2 environment, in which (i) fire occurred at prescribed return intervals; (ii) at the time of fire, each aboveground carbon pool $\mathrm{C}_{j}$ was instantaneously depleted by $f_{\mathrm{b}} \beta_{j} \mathrm{C}_{j}$ with $\beta_{j}$ being a set of prescribed burning efficiencies for each aboveground pool and $f_{\mathrm{b}}$ the fraction of area burned. Burning efficiencies were assigned according to values used by Barrett (2010). The fraction burned area was calculated as

$f_{\mathrm{b}}=\frac{\left(r \mathrm{NPP}_{t}\right)}{\sum_{j} \beta_{j} \mathrm{C}_{j}}$

with $r$ a prescribed ratio of gross fire emissions to NPP (Table 2, Sect. 4.2.2 below) and $\mathrm{NPP}_{t}$ the NPP accumulated since the last burn. Gross fire emissions in this simulation are thus equal to $r \mathrm{NPP}_{t}$.

Relative uncertainty in the mean net fire emissions was assumed equal to that of the gross fire emissions.

\subsection{Land use change and harvest}

For land use change (LUC), flux estimates $\left(F_{\text {LUC }}\right)(1990$ 2008) were extracted from the Australian National Greenhouse Gas Inventory (DCCEE, 2012), and associated data files (UNFCCC, 2011; v.1.4). The component extracted is the one consistent with the Kyoto Protocol article 3.3 which focuses on emissions from deforestation and reforestation. Estimates of $F_{\text {LUC }}$ are calculated using the Australian National Carbon Accounting System (NCAS), a greenhouse accounting framework for the land sector. It is based on spatially explicit ecosystem modelling that uses extensive groundbased datasets for parameterization and validation, and Landsat data time series at 25-m resolution (Richards and Brack, 2004; Waterworth and Richards, 2008; Waterworth et al., 2007).

The LUC flux from NCAS includes emissions from converting forest to cropland and to grassland, and afforestation largely from the conversion of grasslands to forest land (i.e. plantations). The FullCAM model, used as part of NCAS, estimates emissions and removals from all pools including living biomass, dead organic matter, and soil (Richards and Evans, 2004).

Forests lands are defined as lands with a minimum tree cover of $20 \%$ and trees with a minimum height of $2 \mathrm{~m}$. These criteria are consistent with the reporting requirements of the UNFCCC Marrakech Accords, Montreal Process, and the Food and Agriculture Organization. For land conversion, e.g. forest to grassland, a minimum conversion area of 0.2 ha is used. Emissions from fires associated with land use change are accounted for under fire emissions. 
Table 1. Components of the Australian carbon budget.

\begin{tabular}{|c|c|c|c|c|c|}
\hline & & $\begin{array}{r}\text { Flux (away } \\
\text { from land } \\
\text { surface) } \\
{\left[\mathrm{TgC} \mathrm{yr}^{-1}\right]^{\mathrm{a}}}\end{array}$ & $\begin{array}{l}\text { IAV } \\
(1 \sigma)\end{array}$ & $\begin{array}{r}\text { error on } \\
\text { mean } \\
(1 \sigma)\end{array}$ & $\begin{array}{r}\text { averaging } \\
\text { period }\end{array}$ \\
\hline \multirow{5}{*}{$\begin{array}{l}\text { Biosphere (no fire, } \\
\text { no transport, } \\
\text { no harvest, } \\
\text { no LUC) }\end{array}$} & GPP & -4110 & 345 & 740 & $1990-2011$ \\
\hline & RA & 1900 & 154 & 342 & 1990-2011 \\
\hline & NPP & -2210 & 195 & 398 & \\
\hline & $\begin{array}{l}\mathrm{RH}_{-\mathrm{F}-\mathrm{T}-\mathrm{H}} \text { (no fire, } \\
\text { no transport, no harvest) }\end{array}$ & 2130 & 66 & 383 & \\
\hline & $\mathrm{NEP}=\mathrm{NPP}-\mathrm{RH}_{-\mathrm{F}-\mathrm{T}-\mathrm{H}}$ & -80 & 136 & 28 & \\
\hline \multirow[t]{5}{*}{ Fire } & Fire (non-clearing) & 104 & 30 & 19 & \\
\hline & Fire (clearing) & 23 & 5 & 4 & 1990-2010 \\
\hline & Total fire & 127.0 & 30 & 22 & 1997-2009 \\
\hline & $\begin{array}{l}\mathrm{RH}_{-\mathrm{T}-\mathrm{H}} \text { (corrected } \\
\text { for fire) }\end{array}$ & 2029 & 66 & 342 & \\
\hline & $\begin{array}{l}\text { Net fire }=\text { F Fire }+ \\
\text { RH }_{-T-H}-\text { RH }_{-F-T-H}\end{array}$ & 26 & 30 & 4 & \\
\hline \multirow[t]{3}{*}{ Transport } & Riverine & 2.3 & - & 1 & \\
\hline & Dust & 1 & - & 1 & \\
\hline & Total Transport & 3 & - & 1 & \\
\hline \multirow{12}{*}{$\begin{array}{l}\text { Harvest (wood, } \\
\text { livestock, crops) }\end{array}$} & HWP gross & 6.1 & - & 1.5 & 2004 \\
\hline & HWP consumption & 6.4 & - & 2 & 2004 \\
\hline & HWP export & -0.3 & - & 2 & 2004 \\
\hline & Livestock gross & 3.1 & - & 0.8 & 2004 \\
\hline & Livestock consumption & 2.0 & - & 0.5 & 2004 \\
\hline & Livestock export & 1.1 & - & 0.3 & 2004 \\
\hline & Crop gross & 19.6 & - & 5 & 2004 \\
\hline & Crop consumption & 8.9 & - & 2 & 2004 \\
\hline & Crop export & 10.7 & - & 3 & 2004 \\
\hline & Harvest gross & 29 & - & 7 & \\
\hline & Harvest export & 12 & - & 3 & \\
\hline & Harvest consumption & 17 & - & 4 & \\
\hline $\begin{array}{l}\text { Heterotrophic } \\
\text { Respiration }\end{array}$ & $\begin{array}{l}\text { RH (corrected for fire, } \\
\text { harvest, transport) }\end{array}$ & 1997 & 66 & 383 & \\
\hline Land use change & LUC & 18 & - & 7 & 1990-2009 \\
\hline \multirow{2}{*}{ Fossil fuels } & FF (territorial) & 95 & - & 6 & 1990-2011 \\
\hline & FF (export) & 140 & - & 8 & 1990-2011 \\
\hline \multirow[t]{2}{*}{ Net fluxes } & NBP & -36 & 139 & 29 & \\
\hline & Land-atm exchange & 43 & 139 & 29 & \\
\hline \multirow[t]{6}{*}{ Changes in Stock ${ }^{b}$} & $\Delta \mathrm{C}_{\mathrm{FF}} / \mathrm{d} t$ & -235 & - & 15 & \\
\hline & $\Delta \mathrm{C}_{\text {Non-Territorial }} / \mathrm{d} t$ & 155 & - & 17 & \\
\hline & $\Delta \mathrm{C}_{\text {Biosphere }} / \mathrm{d} t$ & 36 & 139 & 29 & \\
\hline & $\Delta \mathrm{C}_{\text {Territorial }} / \mathrm{d} t$ & -198 & 139 & 38 & \\
\hline & $\Delta \mathrm{C}_{\mathrm{HWP}} / \mathrm{d} t$ & 1 & - & - & \\
\hline & $\Delta \mathrm{C}_{\text {Atmosphere }} / \mathrm{d} t$ & 198 & 139 & 38 & \\
\hline
\end{tabular}


For harvested products, the Australian National Carbon Accounting System (NCAS) accounts for the change in stock of harvested wood products (HWP). This stock includes wood products from forest land within Australia plus imported material minus exported material. Descriptions of the methods and data sources are described in DCCEE (2012), and details of the wood products model and accounting framework are described in Richards et al. (2007).

Production, consumption and export of C in HWP, crops and livestock feed consumption were estimated using the methodology of Peters et al. (2012), applied to Australia for this work. The livestock feed consumption data were converted to carbon content of livestock using the livestock conversion efficiency factor (for Oceania) of $3.7 \%$ from Kraussmann et al. (2008) (Table 6).

For uncertainties of LUC emissions, we assumed the global value of $40 \%(1 \sigma)$ (Le Quere et al., 2009), while for fluxes of harvested products, we assume uncertainties of $25 \%(1 \sigma)$.

\subsection{Riverine transport}

Freshwater fluxes of dissolved organic carbon (DOC), which we assume is of terrestrial origin, are computed as the product of a representative DOC concentration and the mean annual river flow.

River flow is taken to be either the modelled runoff from one of several significant recent studies of surface water resources in Australia (e.g. Raupach et al., 2009; CSIRO, 2008) or, for the catchments of the Great Barrier Reef lagoon, measured annual discharge from the Short Term Modelling Project (Cogle, Carroll, and Sherman, 2006) and from Furnas (2003).

A database of DOC concentrations for Australian continental rivers was assembled from the literature (e.g. Bass et al., 2011). These data were used to estimate mean DOC concentrations as follows: the Australian continent is broken up into 246 distinct hydrographic basins (a.k.a. surface water management areas) (ASWMA, 2004). Where data were available for more than one river within a basin, a flowweighted mean concentration was computed from the observations and assigned to the entire basin. This concentration was multiplied by the total basin runoff to give the DOC flux for the basin. For calculating fluxes to the ocean, the 246 basins were aggregated to areas contributing to 7 COSCAT zones (COastal Segmentation and related CATchments), based on a combination of coastal shelf morphology, coastal current patterns, and climate gradients (Meybeck et al., 2006), as shown in Fig. 13. Fluxes were calculated on a COSCAT zone basis as the product of the relevant annual runoff and a representative concentration. The representative concentration was computed as a flow-weighted average from the constituent basins. In the absence of any measured DOC data, a value was assigned using judgement to interpo- late between basins with observational data and considering the local landscape and hydrologic attributes.

In the absence of uncertainty estimates, we assign a relative uncertainty of $50 \%$ on this component of the $\mathrm{C}$ budget. This crude estimate has negligible impact on the uncertainty of NBP, because the $\mathrm{C}$ flux associated with riverine transport is very small (Sect. 4.4).

\subsection{Dust export}

Net dust export from Australia is equal to gross dust emissions minus wet and dry dust deposition terms. Estimates of these terms were obtained from a literature survey of studies (Ginoux et al., 2004; Li et al., 2008; Luo et al., 2003; Miller et al., 2004; Tanaka and Chiba, 2006; Werner et al., 2002; Yue et al., 2009; Zender et al., 2003) that use global atmospheric/chemical transport models and/or climate models, specifically enabled to simulate the uplift, transport and wet/dry deposition of dust. Li et al. (2008) specifically target regions in the Southern Hemisphere. Of the eight studies, only four provided full dust budgets. The mean ratio of net dust export to gross dust emissions for Australia obtained from these four studies was applied to the gross emissions of the remaining four studies.

Export of carbon by dust is estimated by multiplying net dust export by a fixed soil organic content (SOC) of dust, taken as $4 \pm 3 \%$. This value is based on a range of $1-7 \%$ SOC observed in wind-blown sediment samples in a recent study indicating significant enrichment of carbon in Australian dusts relative to parent soils (Webb et al., 2012).

Uncertainty in this flux component of the $\mathrm{C}$ budget is assumed as $100 \%$ of the flux, based on the large uncertainty in the soil organic carbon content of dust and the large range of net dust export estimates (Sect. 4.5). This crude estimate has negligible impact on the uncertainty of NBP, because the C flux associated with dust transport is very small (Sect. 4.5).

\subsection{Fossil fuel}

Fossil fuel emissions estimates (1990-2010) for construction of the Australian full carbon budget were obtained from the latest available Australian National Greenhouse Gas Inventory (DCCEE, 2012). These were extrapolated to 2011 before averaging over the 1990-2011 period. The C-flux embodied in fossil fuel exports (2009-2010) was derived from fuel export data (ABARES, 2011), and extrapolated to the full budget period by assuming a constant growth rate of $0.06 \mathrm{yr}^{-1}$. For calculation of embodied carbon emissions and comparisons with other countries, we used the dataset of the Carbon Dioxide Information and Analysis Center (CDIAC) (Andres et al., 2012; Boden et al., 2011; Marland and Rotty, 1984). For uncertainties of FF emissions, we assumed the global value of $6 \%(1 \sigma)$ (Andres et al., 2012). This global value is applicable to Australia, because, although fossil fuel 
Table 2. Ratio of annual gross fire emissions and annual net fire emissions to mean NPP (1990-2011): mean ratio; IAV of ratio and maximum ratio for the 1997-2009 period.

\begin{tabular}{lrrr|rrr}
\hline & \multicolumn{3}{c|}{$\begin{array}{c}\text { Gross fire emissions/ } \\
\text { mean NPP }\end{array}$} & \multicolumn{3}{c}{$\begin{array}{c}\text { Net fire emissions/ } \\
\text { mean NPP }\end{array}$} \\
\cline { 2 - 7 } & mean & IAV $(1 \sigma)$ & $\max$ & mean & IAV $(1 \sigma)$ & $\max$ \\
\hline Tropics & 0.18 & 0.04 & 0.24 & -0.015 & 0.003 & 0.001 \\
Savanna & 0.09 & 0.03 & 0.15 & -0.002 & 0.0006 & 0.000 \\
Warm Temp & 0.01 & 0.01 & 0.05 & 0.008 & 0.008 & 0.030 \\
Cool Temp & 0.03 & 0.04 & 0.14 & 0.016 & 0.022 & 0.075 \\
Mediterranean & 0.006 & 0.003 & 0.01 & $1.8 \times 10^{-5}$ & $8 \times 10^{-6}$ & $3 \times 10^{-5}$ \\
Desert & 0.03 & 0.02 & 0.07 & 0.004 & 0.002 & 0.0089 \\
Australia & 0.06 & 0.02 & 0.08 & 0.0014 & 0.003 & 0.0074 \\
\hline
\end{tabular}

consumption is known relatively accurately, the uncertainty of carbon content of coal is $\sim 6 \%$.

\section{The net carbon budget, 1990-2011}

Table 1 summarises the net territorial Australian carbon budget, and it is further distilled in Figs. 1 and 2. Each component is discussed in detail in Sect. 4.

The budget period for each flux component is specified as 1990-2011, and is defined as starting at the beginning of 1990 or whenever data become available thereafter, and ending at the end of 2011, or whenever data cease being available before then. Estimates of NPP and NEP span the entire budget period. Of the remaining fluxes, it is mostly assumed that the average flux over the available years applies to the entire budget period. The exception is fossil fuel emission and export, for which the 1990-2011 values were derived by extrapolation (Sect. 2.6).

For the 1990-2011 period, the biosphere gained carbon at an average rate of $36 \pm 29 \mathrm{TgC} \mathrm{yr}^{-1}$ ( $1 \sigma$ error on mean). As indicated in Figs. 1 and 2i, the gross loss of carbon from the biosphere is dominated by heterotrophic respiration $\left(1997 \pm 383 \mathrm{TgC} \mathrm{yr}^{-1}\right)$, with smaller losses due to fire $\left(127 \pm 22 \mathrm{TgC} \mathrm{yr}^{-1}\right)$, harvest $\left(29 \pm 7 \mathrm{TgC} \mathrm{yr}^{-1}\right)$, land use change $\left(18 \pm 7 \mathrm{TgC} \mathrm{yr}^{-1}\right)$ and transport by rivers and dust

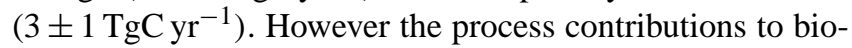
spheric carbon accumulation are quite different. As shown in Fig. 2ii, the net effects of changing climate and rising $\mathrm{CO}_{2}$ are to increase biospheric carbon by $12 \pm 24$ and $68 \pm 7 \mathrm{TgC} \mathrm{yr}^{-1}$ respectively, while fire and LUC cause net respective losses of $26 \pm 4 \mathrm{TgC} \mathrm{yr}^{-1}$ and $18 \pm 7 \mathrm{TgC} \mathrm{yr}^{-1}$. (Harvest and transport are assumed to have no net effect on biospheric carbon accumulation.)

Of the total harvest, $60 \%$ is consumed in Australia and mostly contributes directly to the flux from the Australian territory to the atmosphere. A small part of the wood harvest flux contributes to the accumulation of the HWP stock at a rate of $1 \mathrm{TgC} \mathrm{yr}^{-1}$. The exported harvest is returned to the atmosphere as non-territorial emissions. Small exports of carbon by river $\left(2 \pm 1 \mathrm{TgC} \mathrm{yr}^{-1}\right)$ and dust $\left(1 \pm 1 \mathrm{TgC} \mathrm{yr}^{-1}\right)$ transport also contribute to non-territorial emissions.

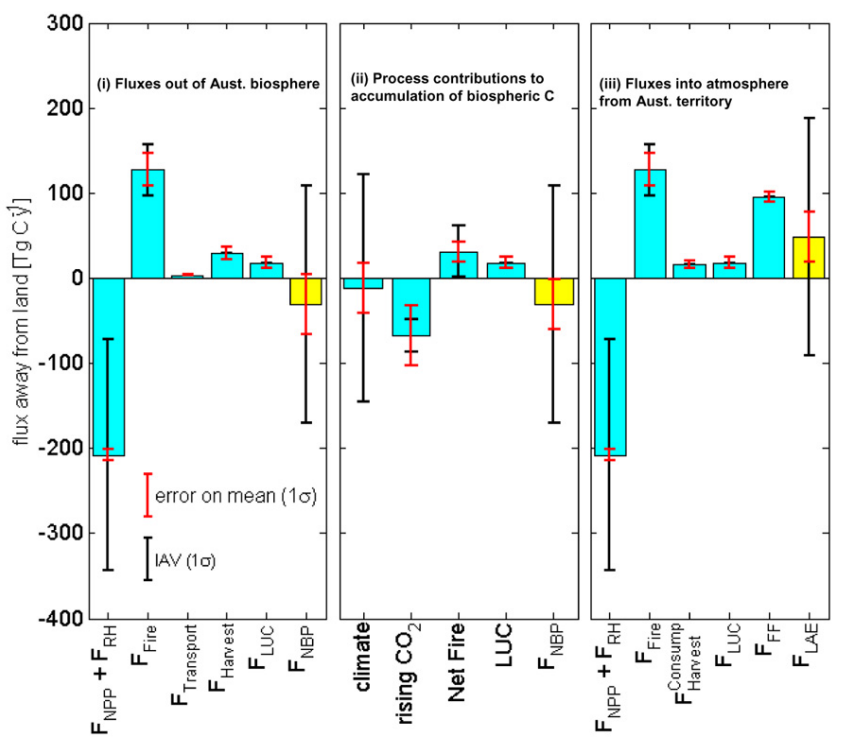

Fig. 2. (i) Net flux of carbon out of the Australian biosphere $\left(F_{\mathrm{NBP}}\right.$, yellow) as the sum of components (blue); (ii) net flux of carbon out of the Australian biosphere ( $F_{\mathrm{NBP}}$, yellow) as the sum of process contributions (blue) due to variable climate, rising $\mathrm{CO}_{2}$, net effect of fire (mainly clearing fires) and LUC; (iii) net flux of carbon from the Australian territory to the atmosphere ( $F_{\mathrm{LAE}}$, yellow), as the sum of components (blue). Error bars represent errors on the mean $(1 \sigma$, red $)$ and interannual variability $(1 \sigma$, black $)$.

During the same period, the stock of carbon in fossil fuels was depleted by $235 \pm 15 \mathrm{TgC} \mathrm{yr}^{-1}$, of which $95 \pm 6 \mathrm{TgC} \mathrm{yr}^{-1}$ were attributable to burning of fossil fuels within the Australian territory, and the remainder to export. Combining territorial fossil fuel emissions with harvest consumption and biospheric land-to-atmosphere fluxes re-

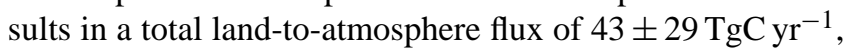

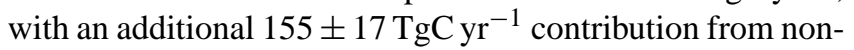
territorial emissions resulting from consumption of Australian harvest and fossil fuels outside of Australia.

Components of the net flux out of the Australian biosphere and the net land-to-atmosphere flux are shown in bar-chart form in Fig. $2 \mathrm{i}$ and iii, along with their $1 \sigma$ uncertainties and interannual variabilities (IAV). The IAV of both net fluxes is dominated by IAV in $\mathrm{F}_{\mathrm{NPP}}+\mathrm{F}_{\mathrm{RH}}\left(136 \mathrm{TgC} \mathrm{yr}^{-1}\right)$, which in turn is largely attributable to IAV in NPP (Table 1).

\section{Components of the net carbon budget}

\subsection{NPP and NEP}

For the purpose of regionalising NPP and NEP, we use the bioclimatic classification shown in Fig. 3, a simple aggregation of classes from the agro-climatic classification of Hutchinson et al. (2005) (Table 2, Fig. 3), which itself is a digital reanalysis for Australia of the global scheme of Hutchinson et al. (1992). Table 3 gives spatial extent, mean 


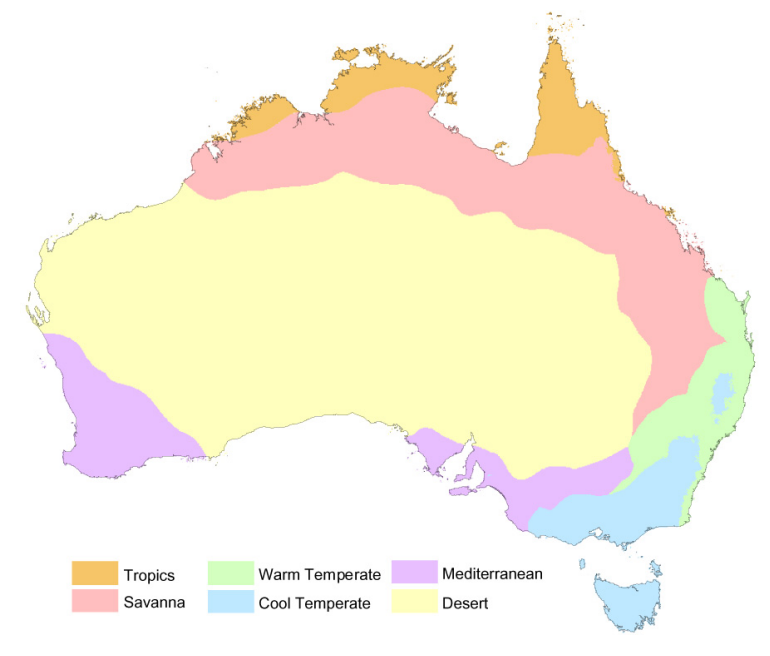

Fig. 3. Bioclimatic classification for use in regionalisation of results.

annual temperature and precipitation (1975-2011) for each bioclimatic region.

\subsubsection{Spatial distribution of mean NPP}

Figure 4 shows the spatial distribution of mean NPP (19902011) at $0.05^{\circ}$ spatial resolution across the Australian continent, as simulated using BIOS2. Spatially and temporally variable drivers are meteorological inputs (air temperature, incoming solar radiation, precipitation), vegetation cover (total leaf area index and its partition into woody and grassy components) and soil properties (temporally invariant). Solid lines in Fig. 4 indicate the boundaries of the bioclimatic regions (Fig. 3) and emphasise the strong climate dependence of NPP. The NPP is strongly weighted to the eastern, northern and south-western margins of the continent, with the remainder of the continent having very low mean NPP.

\subsubsection{Ranking the 1990-2011 period}

It is important to assess the 1990-2011 period in the context of longer-term variability. Figure 5 shows the annual temporal variations of continental mean precipitation, NPP, and NEP, for 1911-2011. Precipitation is included because it is the single largest driver of variability in the Australian carbon cycle. We assessed the representativeness of precipitation, NPP and NEP during 1990-2011 compared with other $22-y r$ periods in Fig. 5. The assessment was done by (i) constructing moving average and standard deviation time series of each quantity using a 22-yr window period; and (ii) converting each point in the time series to a percentile rank (i.e. the percentage of points in the time series that have lower values than the point in question).

Results are shown in Fig. 6, for each bioclimatic region of Fig. 3 and for the whole continent. The final point in each time series is the percentile rank for the 1990-2011 period.

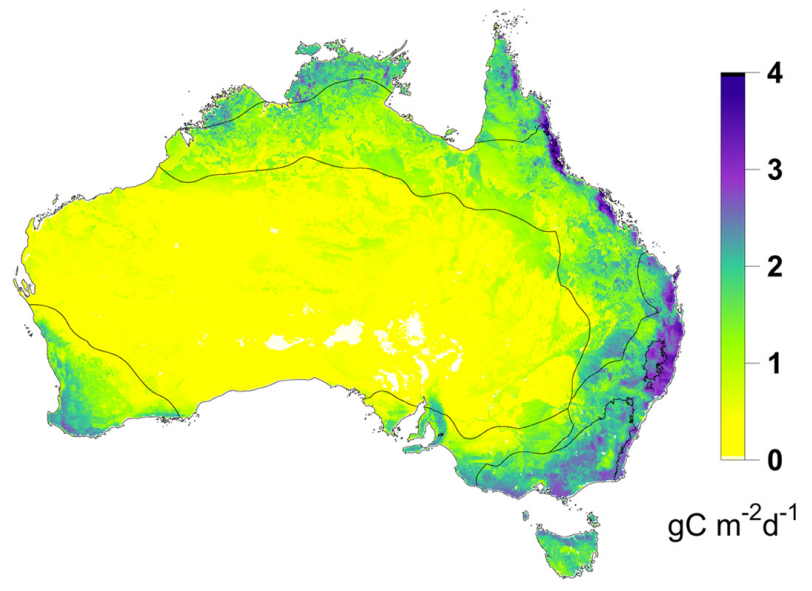

Fig. 4. Mean NPP (1990-2011), with boundaries of bioclimatic regions (Fig. 3, Table 5) indicated as solid lines.

Table 3. Spatial extent, mean annual temperature and precipitation of the bioclimatic regions shown in Fig. 3.

\begin{tabular}{lrrrr}
\hline & $\begin{array}{r}\text { Area } \\
{\left[10^{6} \mathrm{~km}^{2}\right]}\end{array}$ & $\begin{array}{r}\text { Fractional } \\
\text { area } \\
{[\%]}\end{array}$ & $\begin{array}{r}\text { Mean annual } \\
\mathrm{T}(1975-2011) \\
{\left[{ }^{\circ} \mathrm{C}\right]}\end{array}$ & $\begin{array}{r}\text { Mean annual } \\
\text { precip. } \\
(1975-2011) \\
{\left[\mathrm{mm} \mathrm{yr}^{-1}\right]}\end{array}$ \\
\hline Tropics & 0.39 & 5.07 & 26.4 & 1345 \\
Savanna & 1.62 & 21.31 & 24.2 & 704 \\
Warm Temperate & 0.32 & 4.27 & 17.2 & 808 \\
Cool Temperate & 0.34 & 4.47 & 12.4 & 881 \\
Mediterranean & 0.55 & 7.22 & 16.8 & 420 \\
Desert & 4.39 & 57.66 & 21.8 & 296 \\
\hline
\end{tabular}

The $\mathrm{x}$-axis represents the centre year of each 22-yr period. Several features emerge from Fig. 6: (i) at the decadal time scale, NPP is strongly correlated with precipitation; (ii) variability in NEP is more noisy (occurs at shorter time scales) than variability in NPP; (iii) Mediterranean, cool temperate and warm temperate regions have experienced below-median rainfall in each 22-yr period from 1986 onwards (including 2010-2011, widely perceived as the break of a major drought from 2000-2009); (iv) in contrast, the tropics, savanna, desert and the continent as a whole have experienced above-median rainfall during the same period; (v) the rankings of precipitation and NPP for the whole of Australia are very similar to those for the desert region; (vi) continental NEP reveals additional structure not seen in the desert, particularly a decline in the periods from 1986-1997, associated with the tropics and savanna regions.

Figure 7 shows the percentile rank of the 1990-2011 mean and standard deviations of precipitation, NPP and NEP, relative to every other 22-yr period since 1911 . The period 1990 2011 was one of extremes in many respects: (i) precipitation in the tropics, savanna, desert and the whole of Australia was exceptionally high (cumulative probability $\mathrm{CP}>99 \%$ ) and variable (CP > 90\%); (ii) NPP and NEP were correspondingly high and highly variable in the savanna, desert 

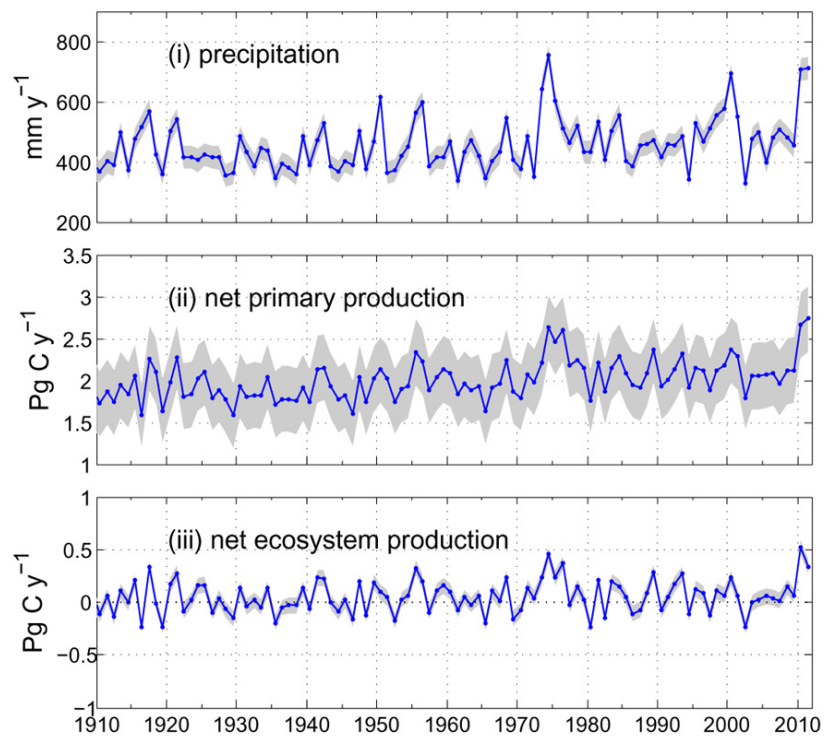

Fig. 5. Annual time series of Australian continental (i) precipitation; (ii) NPP; and (iii) NEP (NPP - RH in the absence of fire and harvest). Shading represents $1 \sigma$ uncertainties on the mean, and includes contributions from parameter uncertainties and forcing uncertainties, as evaluated in Haverd et al. (2012).

and the whole of Australia (CP $>85 \%$ ), but less so in the tropics, where variability in temperature (particularly its influence on vapour pressure deficit) strongly influences variability in NPP and NEP; (iii) the cool temperate region suffered from exceptionally low precipitation $(\mathrm{CP}<10 \%)$ and NEP $(\mathrm{CP}<3 \%)$, as a consequence of preceding decades of below-median NPP (Fig. 6).

\subsubsection{Mean NPP 1990-2011}

Mean NPP for each bioclimatic region and for the whole of Australia is shown in Fig. 8i, simulated at constant $\mathrm{CO}_{2}$ (280 ppm, a pre-industrial concentration), and with actual (rising) $\mathrm{CO}_{2}$. Error bars represent $1 \sigma$ uncertainties due to uncertainties in model parameters and forcing. The parameter uncertainty component represents the constraint on NPP predictions provided by multiple observation sets in the parameter estimation process (Haverd et al., 2012). The Australian continental mean value (with rising $\mathrm{CO}_{2}$ forcing) on a per unit area basis is $0.76 \mathrm{~g} \mathrm{~m}^{-2} \mathrm{~d}^{-1}$, equivalent to $73 \%$ of the global mean of $1.04 \mathrm{~g} \mathrm{~m}^{-2} \mathrm{~d}^{-1}$ for a global land NPP of $55 \mathrm{PgC} \mathrm{yr}^{-1}$ (Cramer et al., 2001) and $56 \pm 14 \mathrm{PgC} \mathrm{yr}^{-1}$ (Ito, 2011). This is taking Australia as $5.5 \%$ of the global land area, and excluding Greenland and Antarctica. Rising $\mathrm{CO}_{2}$ increases continental NPP by $13 \%$ compared with steady preindustrial forcing. Higher increases of $15-16 \%$ occur in the tropics, savanna and desert (which are subject to very high temperatures and humidity deficits) and lower values of $9-10 \%$ in the temperate and Mediterranean regions. The response of NPP to rising $\mathrm{CO}_{2}$ is also shown in time series

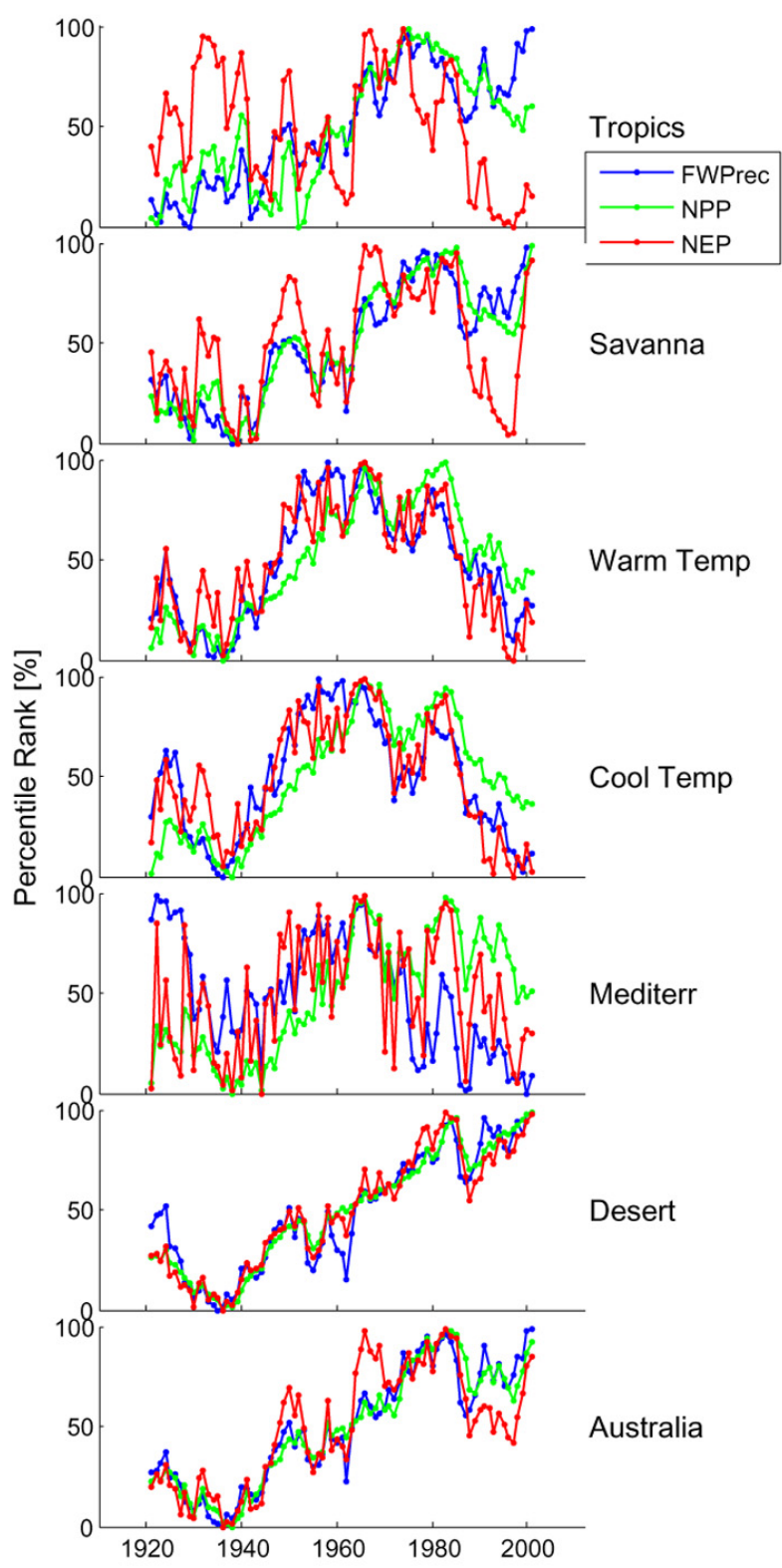

Fig. 6. Percentile rank time series of $22-y r$ averaged precipitation, NPP and NEP. Each point is the percentile rank of the variable (precipitation, NPP or NEP), averaged over a 22-yr window, centered at the time on the $\mathrm{x}$-axis. A point having a percentile rank of $100 \%$ means that all other points in the time series have lower values.

form in Fig. 8i. Each time series is the difference between NPP simulated at "rising $\mathrm{CO}_{2}$ " and "constant $\mathrm{CO}_{2}$ ", relative to the "constant $\mathrm{CO}_{2}$ " NPP.

\subsubsection{Mean NEP 1990-2011}

Non-zero mean NEP (1990-2011) simulated by BIOS2, and shown in Fig. 9ii, is the consequence of variable meteorological forcing ("constant $\mathrm{CO}_{2}$ ") and a combination of variable meteorological forcing and $\mathrm{CO}_{2}$ forcing ("rising $\mathrm{CO}_{2}$ "). 

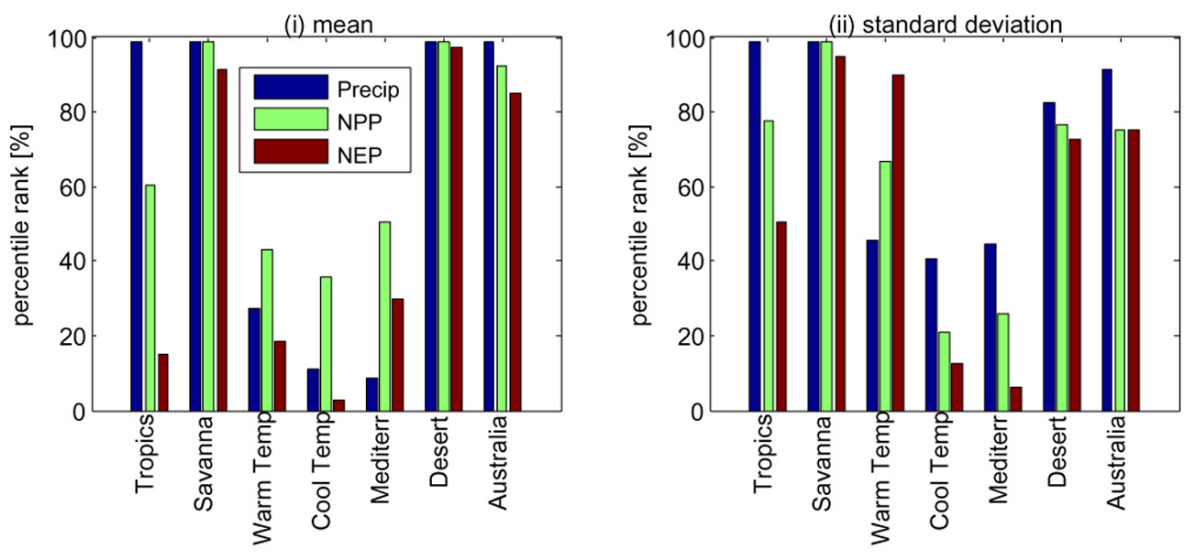

Fig. 7. Percentile ranks of the 1990-2011 (i) mean and (ii) standard deviation of precipitation, NPP and NEP, relative to all other 22-yr periods starting in successive years from 1911.

Responses of NEP to $\mathrm{CO}_{2}$ are plotted in Fig. 9ii. Interannual variations in the NPP responses (Fig. 9i) are amplified in the NEP responses because of the time delay between a change in NPP and the consequent change in RH. For clarity, the responses are replotted in Fig. 9ii (inset) as 22-yr running means, revealing distinct responses for the different regions. The largest response is in the desert region ( $4.5 \%$ of NPP in 2011), and the response for Australia is $3.5 \%$ of NPP in 2011.

Fig. 8ii shows that, with constant $\mathrm{CO}_{2}$ forcing, the tropics, warm temperate and cool temperate regions would be significant sources of $\mathrm{CO}_{2}$ to the atmosphere, because the averaging period (1990-2011) is preceded by a long period of declining NPP (Fig. 6). However, the $\mathrm{CO}_{2}$ response is sufficiently strong that each bioclimatic region, and the whole of Australia, is a net sink under a regime of no disturbance. Error bars represent the $1 \sigma$ uncertainties in NEP resulting from $20 \%$ uncertainty in the partial derivative of NPP with respect to atmospheric $\mathrm{CO}_{2}$ concentration, combined in quadrature with uncertainties due to uncertainties in model parameters and forcing. The continental NEP values of $0.004 \mathrm{~g} \mathrm{~m}^{-2} \mathrm{~d}^{-1}$ (constant $\mathrm{CO}_{2}$ ) and $0.029 \mathrm{~g} \mathrm{~m}^{-2} \mathrm{~d}^{-1}$ (rising $\mathrm{CO}_{2}$ ) are equivalent to respective continental sinks $12 \mathrm{TgC} \mathrm{yr}^{-1}$ and $80 \mathrm{TgC} \mathrm{yr}^{-1}$. The sink under rising $\mathrm{CO}_{2}$ is $59 \%$ of the mean terrestrial global sink (assuming a 1990-2011 average global sink of 2.6 $\mathrm{PgC} \mathrm{yr}^{-1}$ (Canadell et al., 2007; Pan et al., 2011), and taking the Australian land surface are as $5.5 \%$ of the global land surface, excluding Greenland and Antarctica). However the combined effects of fire and LUC (Fig. 2ii) reduce the continental biospheric sink to $36 \mathrm{TgC} \mathrm{yr}^{-1}$ or $27 \%$ of the global mean sink per unit area.

\subsubsection{Interannual variability}

As seen in the time series of Fig. 5, interannual variability (IAV) of continental NPP and NEP is strongly associated with IAV in rainfall. For the 1990-2011 period, IAV $(1 \sigma)$ of NPP, relative to mean NPP, is $9 \%$ for the continent, with high values of $14-15 \%$ in the savanna, warm temperate, Mediterranean and desert regions, and lower values of $8 \%$ in the tropics and cool temperate regions. The IAV of NEP is similar in absolute magnitude to that of NPP, with a continental value of $8 \%$, relative to mean NPP.

\subsection{Fire}

\subsubsection{Gross fire emissions}

Figure 10i compares gross annual fire emissions derived using the GFED and NGGI methodologies. Each point represents an annual state (administrative unit) flux from one of three vegetation classes. The two estimates generally agree well, particularly for the forest and arid rangelands where the NGGI estimates are $20 \%$ lower and $9 \%$ higher respectively than the GFED estimates. The comparison of the savanna woodland estimates is slightly more complex. In this region, the Queensland fuel loads were prescribed by state experts while, for Northern Territory and Western Australia, they were based on field measurements. It is now clear that the Queensland estimates were biased towards heavily grazed regions of Western Queensland where the fuel loads are low in comparison to Cape York Peninsula where most fires occur. Excluding the Queensland data, NGGI estimates for tropical savanna woodland are on average $13 \%$ lower than GFED estimates. Annual continental fire emissions (Fig. 10ii) also agree very well, with a mean bias of $17 \%$ of GFED with respect to NGGI.

Figure 11 shows the spatial distribution of GFED fire emissions by month. Cool temperate fires occur in the Austral summer months (December-March). In contrast, intense fires in the tropics occur May-November, corresponding to the tropical dry season, with late season fires (SeptemberOctober) being more intense. There is a migration of fire 

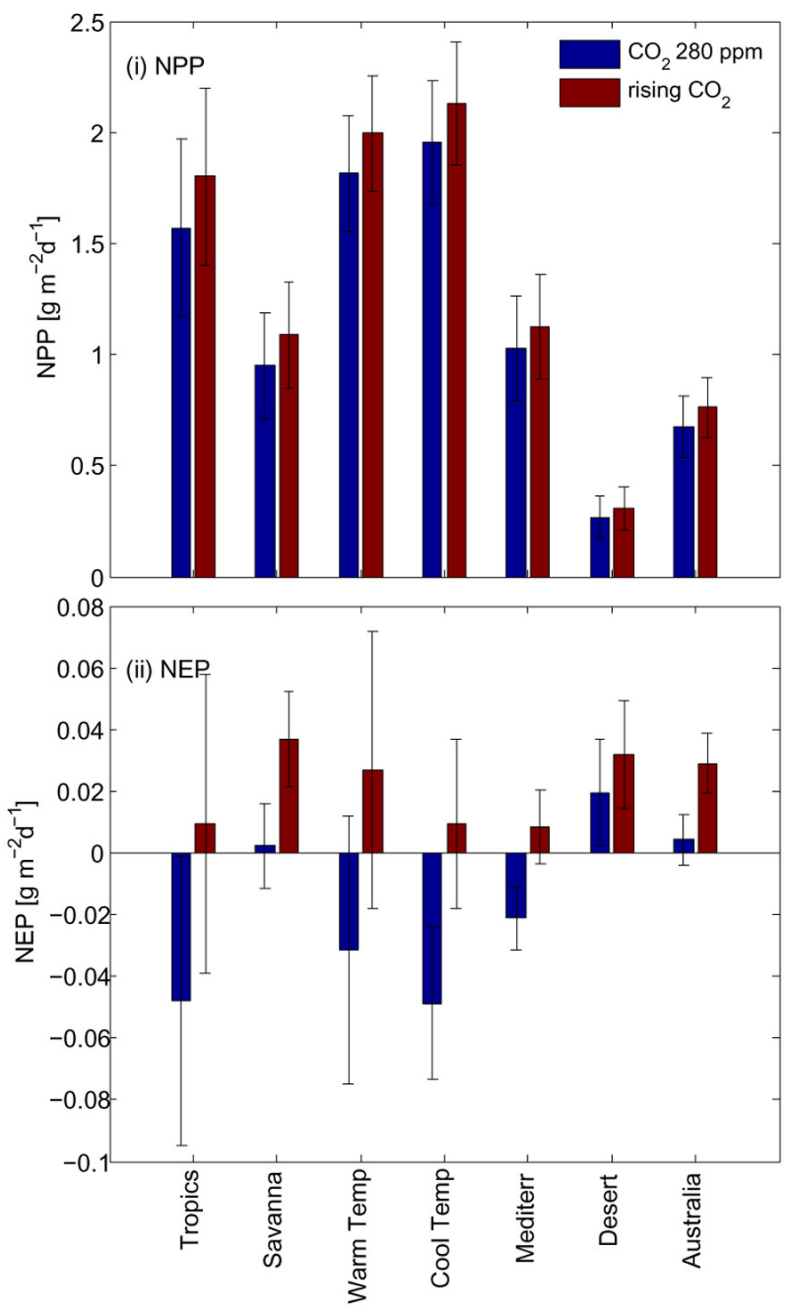

Fig. 8. (i) BIOS2 estimates of 1990-2011 mean NPP under preindustrial $\mathrm{CO}_{2}$ and increasing $\mathrm{CO}_{2}$ forcing. (ii) $\mathrm{BIOS} 2$ estimates of 1990-2011 mean NEP under pre-industrial $\mathrm{CO}_{2}$ and rising $\mathrm{CO}_{2}$. Error bars represent $1 \sigma$ uncertainties on the mean, and include contributions from parameter uncertainties and forcing uncertainties, as evaluated in Haverd et al. (2012).

from west to east across the top end, corresponding to a time lag in the onset of the dry season. During the dry season, the air flows to the north-west from the arid rangelands in central Australia to the Timor Sea and the fetch across the arid interior to north-west Western Australia is particularly long. Hence this region becomes fire prone very early in the season, in contrast to the north east (Cape York, Queensland) where winds are east to south-east, sometimes off the ocean and therefore more humid. The seasonality of fire in the rangelands is more variable than in the tropics; in the south fires occur more frequently in the summer. In the north, the seasonality of monsoons is the main driver.

Figure 12 shows time series of the GFED3 annual gross fire emissions by region. The tropics are a persistently high source of gross fire emissions, while the savanna fire emis-

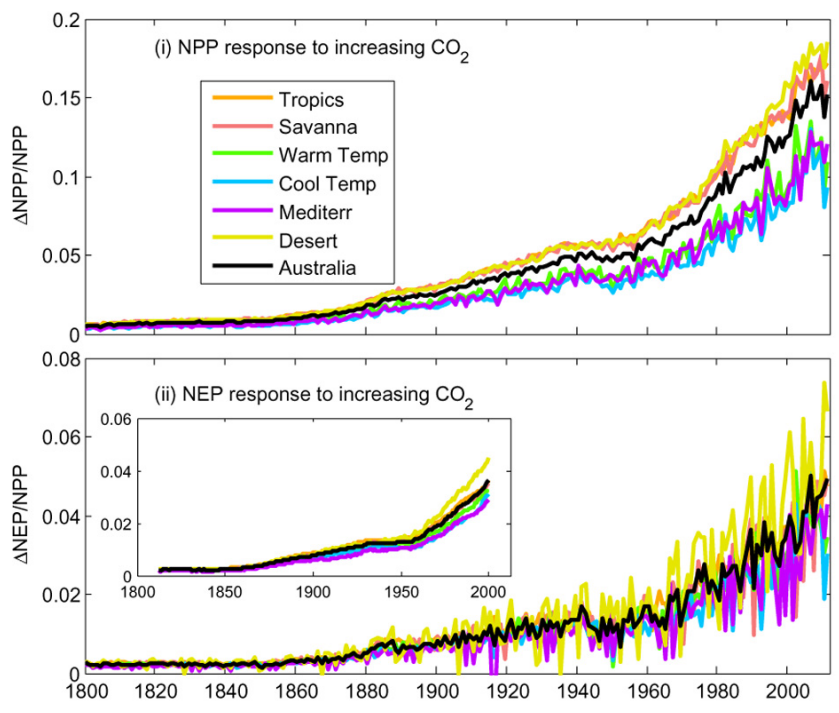

Fig. 9. (i) Response of NPP to increasing $\mathrm{CO}_{2}$, calculated as the difference between NPP simulated with rising $\mathrm{CO}_{2}$ and pre-industrial $\mathrm{CO}_{2}$ (280 ppm), relative to NPP simulated with pre-industrial $\mathrm{CO}_{2}$; (ii) response of NEP to increasing $\mathrm{CO}_{2}$, calculated as the difference between NEP simulated with rising $\mathrm{CO}_{2}$ and pre-industrial $\mathrm{CO}_{2}$, relative to NPP simulated with pre-industrial $\mathrm{CO}_{2}$.

sions are similarly high but show higher IAV, because fuel loads are more variable. The fire events in the desert coincide with years of high NPP associated with large rainfall events; the extreme fire years of 2000 and 2001 followed several extremely wet years in central Australia between 1997 and 1999.

The cool temperate region, usually a small source of fire emissions, produced large emissions in the severe bushfire seasons of 2003 and 2006 during a period of extended drought (seen above in Fig. 6).

In Table 2, we list the mean fraction of NPP burned by region, its variability $(1 \sigma)$, and maximum value. On average, biomass burning represents $6 \%$ of continental NPP, slightly less than the IAV $(1 \sigma)$ of continental NPP (9\%, Sect. 3.1.4) or continental NEP (8\%, Sect. 3.1.4). At $2 \%$ of NPP, the IAV $(1 \sigma)$ of gross fire emissions is small compared to that of NPP or NEP.

\subsubsection{Net fire emissions}

Annual gross fire emissions from non-clearing fires were adjusted using Eq. (4) to obtain net annual emissions from these fires. The correction factor in Eq. (4) was approximated as $\left(1-\frac{F_{\mathrm{RH}, \mathrm{F}-\mathrm{T}-\mathrm{H}}-F_{\mathrm{RH}, \mathrm{T}-\mathrm{H}}}{\mathrm{rNPP}_{t}}\right)$ using consistent estimates of $F_{\mathrm{RH},-\mathrm{F}-\mathrm{T}-\mathrm{H}}, F_{\mathrm{RH},-\mathrm{T}-\mathrm{H}}$ and $\mathrm{rNPP}_{t}$, aggregated spatially over bioclimatic regions and over the 1990-2011 period. The ratio $r$ in Eq. (4) was specified using the mean ratio of gross fire emissions to mean NPP (Table 2), and the fire return interval was specified as $3 \mathrm{yr}$ (tropics and savanna), $50 \mathrm{yr}$ (warm 

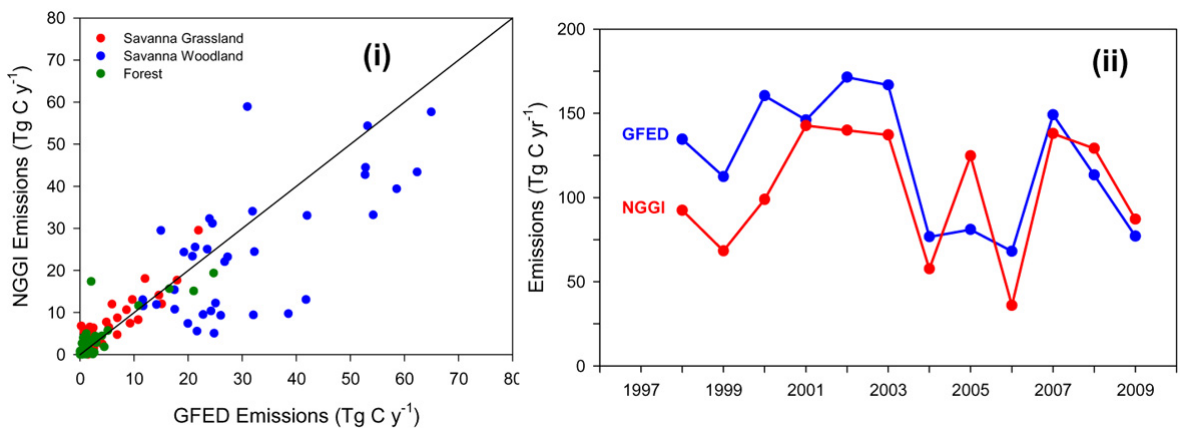

Fig. 10. Comparison of GFED3 and NGGI $\mathrm{CO}_{2}-\mathrm{C}$ gross fire emission estimates. (i) Annual fluxes per state per vegetation class; (ii) total annual Australian continental fire emissions 1997-2009.

temperate and cool temperate) and $20 \mathrm{yr}$ (Mediterranean and desert).

Results for each region and for the Australian continent are listed in Table 2. Net emissions are typically less than $5 \%$ of gross emissions, indicating that, over the averaging period of interest (1990-2011), the C lost due to burning fuel is approximately matched by the additional heterotrophic respiration that occurs in the absence of fire. Significant exceptions are the warm and cool temperate regions, where net fire emissions account for about $60 \%$ of gross fire emissions. The reason for this large fraction is that, owing to the long fire return interval $(50 \mathrm{yr})$, the biosphere does not recover to its pre-fire state within the averaging period (22 yr). Net fire emissions in the tropics and savanna are slightly negative. This does not mean that fire is increasing the uptake of biospheric carbon in the long term. On the contrary, in the absence of fire more carbon is sequestered in the soil over hundreds of years preceding the 1990-2011 period. Because of this and because the period 1990-2011 occurs after an extended decline in NPP (Fig. 7), more C is temporarily being released as RH during 1990-2011 in the simulations with no fire than in the simulations with fire.

The net fire emissions in Table 2 need to be augmented by emissions from clearing fires. Graetz (2002) estimated these to be $18 \pm 10 \mathrm{PgC} \mathrm{yr}^{-1}$ (IAV, $1 \sigma$ ) which is close to the current estimate of $23 \pm 5 \mathrm{PgC} \mathrm{yr}^{-1}$ for 1990-2010 (DCCEE, 2012). Gross emissions from these fires are converted entirely to net emissions (Graetz, 2002).

\subsection{Land use change and harvest}

Net cumulative emissions from land use change were $359 \mathrm{TgC}$ during the 1990-2009 period with mean annual emissions of $21.4 \mathrm{TgC}$ for the $1990 \mathrm{~s}$ and $14.4 \mathrm{TgC}$ for the 2000s.

This cumulative net flux over $20 \mathrm{yr}$ was the result of two major land use changes, the first being the conversion of forest to grassland $(12.9 \mathrm{Mha} ; 359 \mathrm{TgC})$ and forest to cropland (4.4 Mha; $47 \mathrm{TgC}$ ) (Fig. 11). This dominant flux remained quite stable on average throughout the period after an initial decline of $51 \%$ during the period 1990-1995. The flux also takes into account the dynamics of regrowth and re-clearing of forest land, which takes place particularly in the northeast of Australia.

Second, the expansion of new forest largely results from the conversion of grasslands to forest, which creates a $\mathrm{CO}_{2}$ sink (1.1 Mha; $-47.9 \mathrm{TgC}$ ) (Fig. 11). This flux was largely driven by the increase of plantations, which grew from about 1 Mha in 2003 to 1.8 Mha in 2006, largely attributable to the expansion of hardwood plantations, mainly Eucalyptus (Montreal Process Implementation Group for Australia, 2008).

Carbon fluxes for non- $\mathrm{CO}_{2}$ greenhouse gases are negligible for this type of land conversions and not part of the accounting of this paper.

The change in stock of harvested wood products $\Delta \mathrm{C}_{\mathrm{HWP}}$ accounts for a small carbon sink in the context of other major fluxes reported for the Australian terrestrial carbon budget. $\Delta \mathrm{C}_{\mathrm{HWP}}$ was estimated at $1.4 \mathrm{TgC}$ in 1990 , declining to $1.2 \mathrm{TgC}$ in 2009 (DCCEE, 2012). We use an annual average across the period 1990-2009 of $1.3{\mathrm{TgC} \mathrm{yr}^{-1}}^{-1}$.

Production, consumption and export of in HWP, crops and livestock are given in Table 1 for the year 2004, as estimated by Peters et al. (2012), and extracted for Australia for this work. Of these harvest types, crops dominate production $\left(19 \mathrm{TgC} \mathrm{yr}^{-1}\right)$, with smaller productions of HWP $\left(6.4 \mathrm{TgC} \mathrm{yr}^{-1}\right)$ and livestock $\left(3.1 \mathrm{TgC} \mathrm{yr}^{-1}\right)$. In 2004 there was a net import of HWP ( $6 \%$ of production), while $45 \%$ of crop production and $63 \%$ of livestock production were exported.

\subsection{Riverine transport}

The estimated DOC flux has been computed for each COSCAT zone receiving water from Australia (Table 4). There is a trend for DOC concentrations to increase towards the south of the continent relative to the wet tropical regions to the north (Fig. 13). This may reflect longer transit times for rainfall to reach the coast thereby allowing more time for leaching of organic matter. The total DOC flux across 


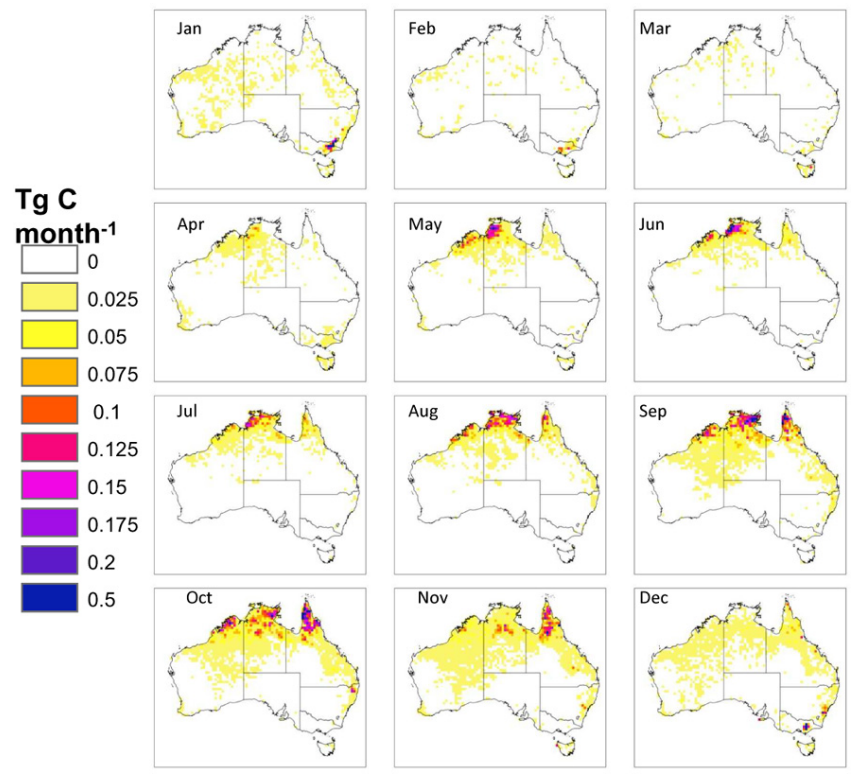

Fig. 11. Ensemble average GFED $\mathrm{CO}_{2}-\mathrm{C}$ gross fire emissions $0.5^{\circ} \times 0.5^{\circ}$ grid cell (1997-2009) by month.

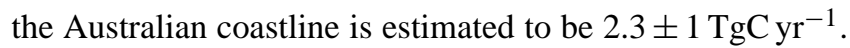
This number is a preliminary estimate and could be refined as more DOC concentration data become available (presently available for only 33 of the total 246 basins).

Runoff estimates for Australia differ by roughly $\pm 5 \%$ (not shown) suggesting a relatively small error in flux estimates is attributable to uncertainty in runoff. Far greater uncertainty can be attributed by the relatively large range of measured values for any given river. This variability must stem in part from the timing of flow events relative to field sampling. Field sampling on a weekly or less frequent basis may miss a significant proportion of the total DOC flux. Bass et al. (2011) suggest that insufficient temporal resolution of DOC measurements can lead to underestimating the flux by a factor of two or more.

There are several significant complications which are not accounted for in the above approach. First, there is no distinction between the DOC flux in the significant portion of runoff that does not reach the sea and that which does. This is probably important: for example, of an estimated $27041 \mathrm{GL} \mathrm{yr}^{-1}$ of gauged runoff within the Murray-Darling Basin, just 4733 GL reach the ocean (CSIRO, 2008). Second, there is a chance that the typical DOC concentrations reported (and used here) have missed the initial surge of leaching and remineralisation which is likely to occur within the first few days of rainfall or flooding after an extended dry period (Glazebrook and Robertson, 1999; Hladyz et al., 2011). Third, remineralisation of DOC as water moves downstream along a river is not accounted for, and is probably important because the fraction of total organic carbon present as DOC can be highly variable (e.g. Vink et al., 2005).

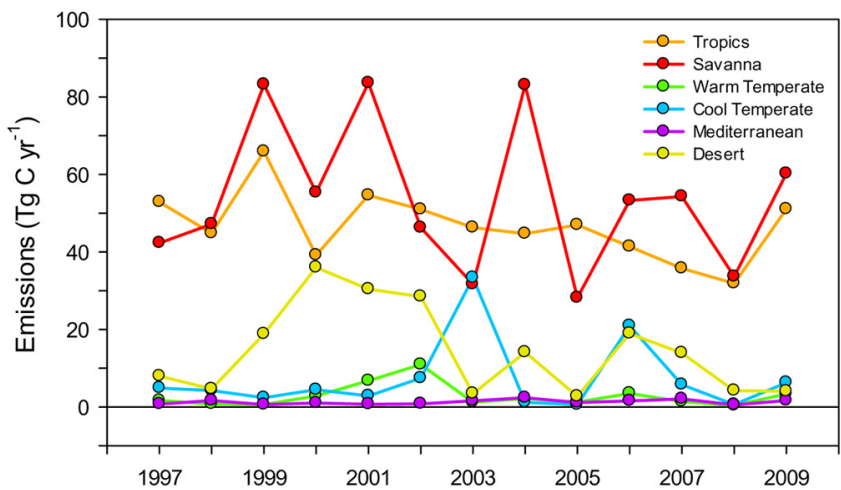

Fig. 12. Annual time series of GFED $\mathrm{CO}_{2}-\mathrm{C}$ gross fire emissions by bioclimatic region.

Table 4. Mean annual runoff (Raupach et al., 2009) draining into Australian COSCAT regions (Fig. 13), mean DOC concentrations computed from observed concentration data (italics denote assumed DOC concentration used to compute DOC fluxes), and DOC fluxes computed using each of the three runoff estimates. Fluxes were calculated using the maximum concentration observed in region 1411.

\begin{tabular}{rrrrr}
\hline $\begin{array}{r}\text { COSCAT } \\
\text { region }\end{array}$ & $\begin{array}{r}\text { Number } \\
\text { of basins }\end{array}$ & $\begin{array}{r}\text { Runoff } \\
{\left[\mathrm{GL} \mathrm{yr}^{-1}\right]}\end{array}$ & $\begin{array}{r}\text { Mean DOC } \\
{[\mathrm{mg} / \mathrm{L}]}\end{array}$ & $\begin{array}{r}\text { DOC flux } \\
{\left[\mathrm{GgC} \mathrm{yr}^{-1}\right]}\end{array}$ \\
\hline$n / a$ interior & 31 & 4830 & 12 & 58 \\
1403 & 62 & 76273 & 6.3 & 481 \\
1410 & 37 & 40157 & 5 & 201 \\
1411 & 95 & 79600 & $3-13.4$ & 1067 \\
1412 & 18 & 3869 & 12.8 & 50 \\
1413 & 13 & 2077 & 13.0 & 27 \\
1414 & 14 & 18284 & 5 & 91 \\
1415 & 55 & 128840 & 2.6 & 335 \\
\hline Total & 325 & 353931 & & 2309 \\
\hline
\end{tabular}

\subsection{Dust transport}

Australia is the largest source of atmospheric dust and subsequent dust deposition (outside Australia) within the Southern Hemisphere (Tanaka and Chiba, 2006). This is primarily due to the arid climate across much of Australia (rainfall $<1 \mathrm{~mm} \mathrm{~d}^{-1}$ ) and consequently low soil moisture and sparse vegetation coverage. Wind erosion is the primary means of dust uplift, although human activities also contribute (Boon et al., 1998). Australian emissions account for $59 \%$ of total Southern Hemisphere emissions, $34 \%$ of the dust burden of the Southern Ocean (Li et al., 2008) and significantly influence atmospheric dust loading within the Southern Hemisphere (Luo et al., 2003). However, Australian emissions only contribute $\sim 5 \%$ to global emissions ( 1000-2000 $\mathrm{Tg} \mathrm{yr}^{-1}$, Tanaka and Chiba, 2006), since major Northern Hemisphere source regions (e.g. northern Africa and Asia) produce substantially larger emissions. The lack of significant influence of Northern Hemisphere dust emissions 
Table 5. Australian continental dust: annual emission, deposition, export and emission as \% global emission.

\begin{tabular}{|c|c|c|c|c|c|c|c|}
\hline Reference & $\begin{array}{c}\text { Emission } \\
{\left[\mathrm{Tg} \mathrm{yr}^{-1}\right]}\end{array}$ & $\begin{array}{r}\text { Total } \\
\text { Depos. } \\
{\left[\mathrm{Tg} \mathrm{yr}^{-1}\right]}\end{array}$ & $\begin{array}{r}\text { Export } \\
{\left[\mathrm{Tg} \mathrm{yr}^{-1}\right]}\end{array}$ & $\begin{array}{r}\% \\
\text { exported }\end{array}$ & $\begin{array}{r}\text { Dry } \\
\text { depos. } \\
{\left[\mathrm{Tg} \mathrm{yr}^{-1}\right]}\end{array}$ & $\begin{array}{r}\text { Wet } \\
\text { depos. } \\
{\left[\mathrm{Tg} \mathrm{yr}^{-1}\right]}\end{array}$ & $\begin{array}{l}\% \text { global } \\
\text { emission }\end{array}$ \\
\hline Tanaka and Chiba (2006) & 106 & 106 & 0 & 0.0 & 65 & 41 & 5.7 \\
\hline Luo et al. (2003) & 132 & 129 & 3 & 2.3 & 70 & 59 & 8.0 \\
\hline Miller et al. (2004) & 148 & 46 & 102 & 68.9 & 44 & 2 & 15.0 \\
\hline Yue et al. (2009) & 73 & 46 & 27 & 37.0 & 38 & 8 & \\
\hline Zender et al. (2003)* & 37 & 27 & 10 & 27.0 & & & 2.5 \\
\hline Ginoux et al. (2004* & 61 & 45 & 16 & 27.0 & & & 2.9 \\
\hline Li et al. $(2008)^{*}$ & 120 & 88 & 32 & 27.0 & & & 5.2 \\
\hline Werner et al. (2002)* & 52 & 38 & 14 & 27.0 & & & 4.9 \\
\hline Mean & 91 & 65 & 26 & 27.0 & & & 6.3 \\
\hline SD & 41 & 37 & 33 & 30 & & & 4.2 \\
\hline
\end{tabular}

* Full dust budget not published. Export and total deposition calculated assuming Export accounts for $27 \%$ of Emission.

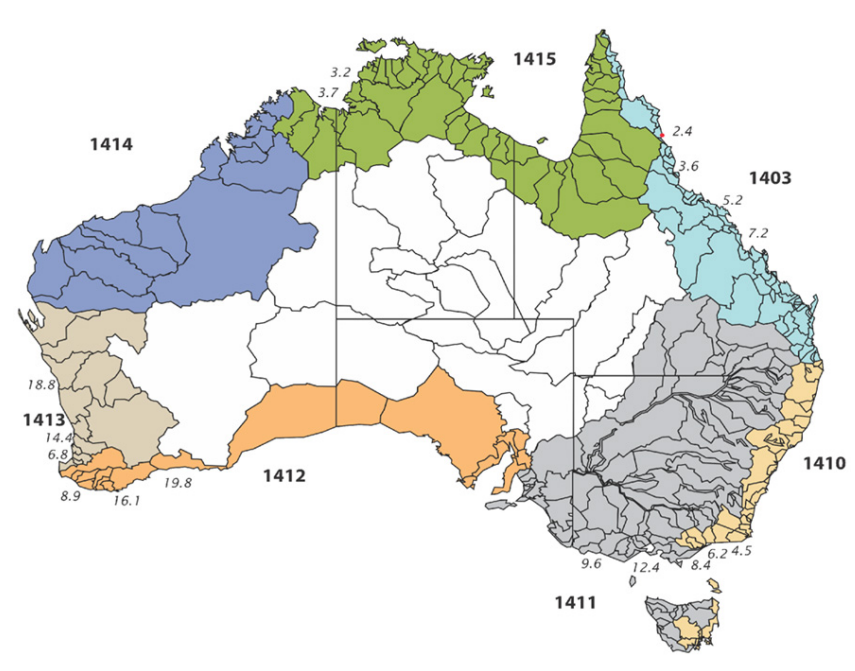

Fig. 13. Australian water catchments grouped by COSCAT zones (filled colours). Bold numbers denote COSCAT zones. Italicised numbers denote representative DOC concentrations $\left[\mathrm{mg} \mathrm{L}^{-1}\right]$ from measurements taken in adjacent catchment rivers. COSCAT zones are based on a combination of coastal shelf morphology, coastal current patterns, and climate gradients (Meybeck, Durr, and Vorosmarty, 2006).

within the Southern Hemisphere is due to the short atmospheric lifetime of dust.

Dust emissions peak from October-February and the major source regions within Australia are the Great Artesian Basin in Central Australia and the Murray-Darling Basin (Li et al., 2008; Maher et al., 2010). Dust emission and export are also characterized by short-lived, sporadic, intense events, sometimes resulting in short-lived, offshore ocean fertilization due to high iron content (Luo et al., 2008). The major pathways of dust export are to the south-east of the continent and, to a lesser extent, the north-west (Maher et al., 2010).

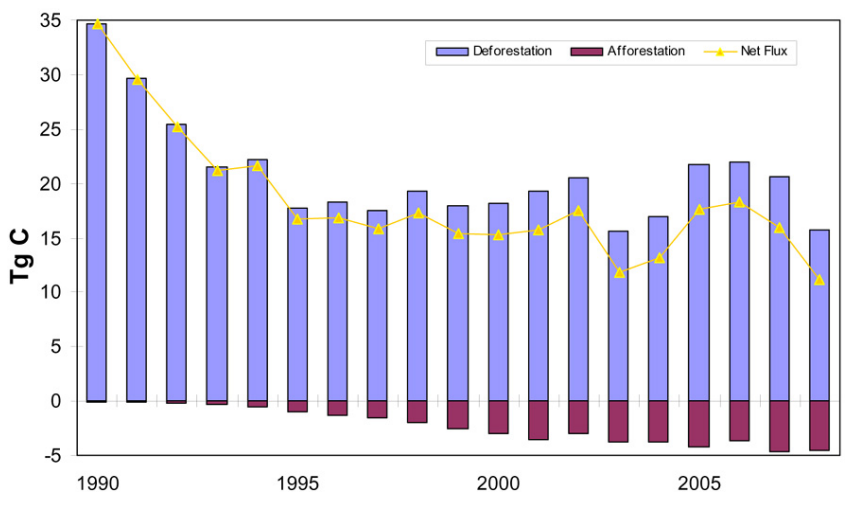

Fig. 14. Annual $\mathrm{CO}_{2}-\mathrm{C}$ fluxes from land use change $(\mathrm{TgC})$.

Both total emission estimates and the fraction of dust exported from Australia vary considerably (Table 5). Of the 8 emission estimates provided in Table 5, only four are accompanied by a full budget, leading to a mean estimate of $27 \%$ of dust emissions being exported out of Australia. Applying this estimate of $27 \%$ to the remaining 4 emission estimates provides a set of 8 estimates of the total mass of dust exported from Australia annually. The mean annual estimate of dust export from Australia is $26 \pm 33(1 \sigma) \mathrm{Tg} \mathrm{yr}^{-1}$. The remaining dust is deposited elsewhere on the Australian continent, primarily through dry deposition (Yue et al., 2009; Tanaka and Chiba, 2006; Luo et al., 2003), although the proportion of dry vs. wet deposition varies significantly.

Assuming a dust carbon content of $4 \pm 3 \%$ (Sect. 2.5 above) and a $100 \%$ uncertainty estimate on net dust export leads to an estimate of $1 \pm 1{\mathrm{TgC} \mathrm{yr}^{-1}}^{-}$.

\subsection{Fossil fuel emissions}

Carbon and green house gas (GHG) accounts are conventionally referenced to territorial regions, and account for emissions from within the region to the atmosphere. On this 


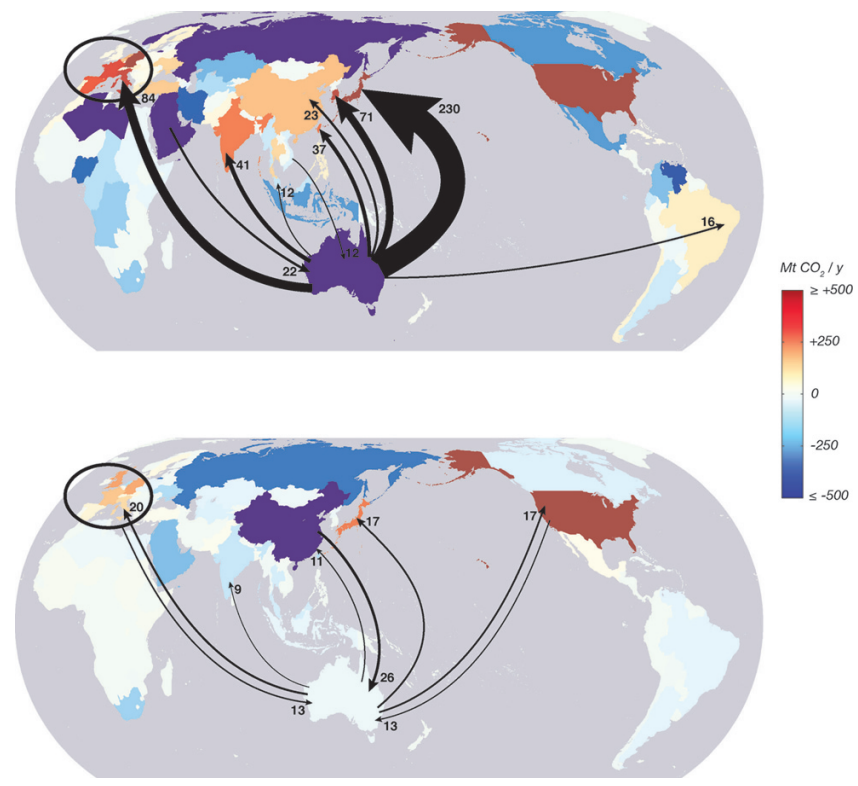

Fig. 15. Millions of tons (Mt) of $\mathrm{CO}_{2}$ embodied in trade in 2004. The upper panel shows regional differences between extraction and production emissions (i.e. the net effect of emissions from traded fossil fuels), and the lower panel shows regional differences between production and consumption emissions (i.e. the net effect of emissions embodied in goods and services). Net exporting countries are shown in blue and net importing countries in red. Arrows in each panel depict the fluxes of emissions $\left(\mathrm{MtCO}_{2} \mathrm{yr}^{-1}\right)$ to and from Australia greater than $9 \mathrm{Mt} \mathrm{CO}_{2} \mathrm{yr}^{-1}$. Fluxes to and from $\mathrm{Eu}-$ rope are aggregated to include all 27 member states of the European Union.

basis, Australia's total GHG emissions in 2009-2010, excluding net $\mathrm{CO}_{2}$ emissions from land use, land use change and forestry (LULUCF), were $148 \mathrm{TgC}^{\mathrm{g}}$-equivalent $\mathrm{yr}^{-1}$, or $543 \mathrm{TgCO}_{2}$-equivalent $\mathrm{yr}^{-1}$ in the units conventionally used in greenhouse accounting (DCCEE, 2012). These $\mathrm{CO}_{2}$ equivalent emissions include all Kyoto GHGs $\left(\mathrm{CO}_{2}, \mathrm{CH}_{4}\right.$, $\mathrm{N}_{2} \mathrm{O}$, HFCs, PFCs, $\mathrm{SF}_{6}$ ). Of these emissions, $\mathrm{CO}_{2}$ makes by far the largest contribution at $110 \mathrm{TgC} \mathrm{yr}^{-1}$, due almost entirely to emissions from fossil fuel combustion. The 19902011 average fossil fuel emission was $95.1 \mathrm{TgC} \mathrm{yr}^{-1}$. Thus, Australia's fossil fuel emissions are both the largest single contribution to its total GHG emissions (about $74 \%$ ), and also a major term in its full carbon budget (Eq. 1).

Australia's emissions have also grown rapidly from 1990 to 2009-2010, the last period for which finalised data are available. Excluding LULUCF, fossil-fuel $\mathrm{CO}_{2}$ emissions have grown by $50 \%$ (76 to $114 \mathrm{TgC} \mathrm{yr}^{-1}$ from 1990 to 2009 2010) and total GHG emissions by $30 \%$ (114 to $148 \mathrm{TgC}$ equivalent $\mathrm{yr}^{-1}$ ). Including LULUCF, the growth in total GHG emissions has been much smaller ( $4 \%$ over $20 \mathrm{yr}$ ), because the baseline year, 1990, was a year of very high LULUCF emissions (DCCEE, 2012) followed by step reductions over the following five years. This will allow Australia to formally meet its Kyoto commitment of an $8 \%$ increase in emissions from 1990 to 2008-2012. However, the underlying emissions growth from fossil fuels is much higher.

The above figures for $\mathrm{CO}_{2}$ emissions for fossil fuels reflect territorial emissions from fossil-fuel combustion within Australia's borders. An even larger contribution comes from export of mined fossil fuels, mainly coal and gas. Australia is the world's largest coal exporter, responsible for about $5 \%$ of total world coal production. Australia's total black (thermal and metallurgical) coal production in 2009-2010 was $356 \mathrm{Mt}$ (about $270 \mathrm{TgC}$, assuming a carbon content of $75 \%$ ), of which $300 \mathrm{Mt}$ coal $(225 \mathrm{TgC})$ was exported, with the major export destinations being Japan, Korea, Taiwan, India and China (ABARES, 2011). Coal exports are growing rapidly $\left(\sim 3 \% \mathrm{yr}^{-1}\right.$ over $2005-2010$, and faster since then). Additional brown coal (lignite) production is around $30 \%$ of black coal production in carbon terms, but is not exported. Gas production for Australia in 2009-2010 was $1954 \mathrm{PJ}$ (petajoules) or about $24 \mathrm{TgC}$, of which about $16 \mathrm{TgC}$ were exported. In liquid fuels (including liquefied petroleum gas, LPG) Australia is a net importer at about $19 \mathrm{GL} \mathrm{yr}^{-1}$ or $15 \mathrm{TgC} \mathrm{yr}^{-1}$ (2009-2010 data; ABARES, 2011). Across all fossil fuels (solid, liquid, gas), Australia's net exports were close to $241 \mathrm{TgC}$ (2009-2010), with black coal being the largest flow by far. This is about twice the territorial $\mathrm{CO}_{2}$ emissions from Australia by fossil fuel combustion. This estimate of FF exports, and the assumption of a fixed growth rate of $0.06 \mathrm{yr}^{-1}$, leads to an estimate of $140 \mathrm{TgC} \mathrm{yr}^{-1}$ for the mean FF export over the 1990-2011 period. Major destination countries included Japan, Korea, Taiwan, India and China (Fig. 15, upper). Australia also imported and burned fossil fuels extracted in other regions, mostly oil from the Middle East and Vietnam (Davis et al., 2011).

\subsection{Embodied carbon flows}

International trade in goods and services also embodies $\mathrm{CO}_{2}$ emissions. For example, emissions produced during the manufacture of goods for export may be attributed to the country where the goods are consumed. In this way, goods and services consumed in Australia in 2004 were associated with $361 \mathrm{Mt} \mathrm{CO}_{2}$, with net exports of $16 \mathrm{Mt} \mathrm{CO}_{2}$ mostly destined for the EU, Japan and the US (Fig. 15, lower). Of exported emissions, the vast majority $(83 \%)$ were embodied in intermediate goods for input to further manufacturing processes elsewhere. Among the exported emissions embodied in final goods, $46 \%$ were associated with just four industry sectors: air transport, machinery, beef, and motor vehicles/parts. Emissions embodied in imports were similarly concentrated in four sectors: machinery, electronic equipment, motor vehicles/parts, and unclassified transport (Davis and Caldeira, 2010).

Australian territorial emissions have grown steadily since 1990 (Sect. 4.6). However, the Australian economy is heavily dependent on mining and energy-intensive manufacturing 
(e.g. aluminium), much of which is exported. When allocating the emissions in Australia required to produce exported products, $25 \%$ (20 TgC) of Australia's carbon emissions in 1990 were from the production of exported products and this almost doubled in size in 2008 to $41 \%$ of the domestic emissions (39 TgC) (Peters et al., 2011, Fig. 1). In terms of imports, in $199010 \mathrm{TgC}$, representing $13 \%$ of Australia's domestic emissions, were emitted in other countries to produce imports into Australia and this more than doubled to $24 \mathrm{TgC}$ (25\%) by 2008 (Peters et al., 2011; Fig. 1). Thus, Australia is a net exporter of carbon emissions to the rest of the world, increasing $50 \%$ from a net export of $10 \mathrm{TgC}(13 \%$ domestic emissions) in 1990 to a net export of $15 \mathrm{TgC}(16 \%)$ in 2008. Consequently, after adjusting for the net trade in embodied carbon emissions (Peters, 2008), consumption-based emissions in Australia are lower than the territorial emissions with the gap increasing over time.

Consumption-based (embodied) carbon emissions and the flows of carbon in traded fossil fuels are not included in territorial or production-based national carbon budgets. However, these flows help to understand the drivers of changes in national emission profiles over time and how they relate to the global total fossil fuel emissions (Peters et al., 2008; Davis and Caldeira, 2010).

\section{Analysis of global inversions}

Fourteen sets of estimated fluxes are available from a range of global inversions (Peylin, 2013). Coarse-resolution inversions (such as the TransCom cases) solve for Australia as a single region combined with New Zealand. Other inversions solve for sub-regions of Australia, or at model grid-scale. However the major limitation of all these inversions is the atmospheric $\mathrm{CO}_{2}$ data for the Australian region. Typically the inversions include flask records at Cape Grim $\left(144.7^{\circ} \mathrm{E}\right.$, $\left.40.7^{\circ} \mathrm{S}\right)$ and Cape Ferguson $\left(147.1^{\circ} \mathrm{E}, 19.3^{\circ} \mathrm{S}\right)$. However these are taken under baseline conditions, which are designed to avoid sampling air that has recently crossed the Australian continent. Some inversions also use aircraft measurements taken on Japan to Sydney flights, but these are from around $10 \mathrm{~km}$ altitude. Thus none of the global inversions considered here includes atmospheric $\mathrm{CO}_{2}$ measurements that are representative of air that has had recent contact with the Australian continent. Consequently the estimated fluxes are highly dependent on prior information included in the inversion, typically fluxes from a biosphere model simulation such as CASA (Randerson et al., 1997).

The inversions were run for different time periods with fossil emissions taken as well known (though not prescribed identically for different inversions). Decadal mean $\left(F_{\mathrm{LAE}}-F_{\mathrm{FF}}\right)$ for Australia ranges from -0.26 to $0.31 \mathrm{PgC} \mathrm{yr}^{-1}$ with most variation being across models and a smaller variation being across the years used to make the decadal mean. Some inversions show decadal mean fluxes that become more negative over time. The inversions with higher fossil emissions do not show correspondingly lower net biosphere fluxes. It is apparent that global inversions driven by baseline $\mathrm{CO}_{2}$ observations provide no meaningful constraint on Australian fluxes.

\section{Summary}

Key findings emerging from the construction of the full Australian carbon budget (1990-2011) are listed below.

1. Climate variability and rising $\mathrm{CO}_{2}$ contributed $12 \pm 24$ and $68 \pm 15 \mathrm{TgC} \mathrm{yr}^{-1}$ to biospheric $\mathrm{C}$ accumulation. The relative contributions of these forcings varied across bioclimatic regions. One extreme was the desert region, where $\mathrm{CO}_{2}$ fertilisation reinforced the positive impact on NEP of extremely high rainfall in 1990-2011, preceded by several decades of increasing rainfall. The other extreme was the cool temperate region where $\mathrm{CO}_{2}$ fertilisation was only just sufficient to offset the negative impact of decades of drought on NEP. The response of NPP to rising $\mathrm{CO}_{2}$ varies regionally, being higher for regions where gross primary production (GPP) is strongly influenced by high humidity deficit.

2. Net ecosystem productivity is partially offset by fire and LUC, which cause net losses of $26 \pm 5 \mathrm{TgC}^{-1}$ and $18 \pm 7{\mathrm{TgC} \mathrm{yr}^{-1}}^{-1}$ from the biosphere. The resultant NBP of $36 \pm 29 \mathrm{TgC} \mathrm{yr}^{-1}$ offsets fossil fuel emissions $\left(95 \pm 6 \mathrm{TgC}^{-1}\right)$ by $32 \pm 30 \%$.

3. Gross fire emissions account for $6 \%$ of continental NPP, approximately the same as the $1 \sigma$ interannual variability in NPP. However net fire emissions, largely associated with clearing fires, account for only $1 \%$ of NPP.

4. Lateral transport of $\mathrm{C}$ as DOC in rivers accounts for $0.1 \%$ of NPP, while net export of $\mathrm{C}$ by dust is smaller at $0.05 \%$. Both transport terms have large uncertainties of $\sim 100 \%$.

5. Land use change emissions (the net effect of deforestation and reafforestation) is a similar magnitude to net fire emissions, accounting for $1 \%$ of NPP.

6. Australia exported 1.5 times as much fossil-fuel carbon as it consumed in territorial emissions (1990-2010). However this ratio is growing rapidly, with 2009-2010 exports being 2.5 times larger than territorial emissions from fossil fuels.

7. The interannual variability in NEP and hence NBP exceeds Australia's total carbon emissions by fossil fuel consumption, and indeed its total anthropogenic GHG emissions accounted under extant territorial GHG inventories. 
8. Global atmospheric inversion studies do not meaningfully constrain the Australian terrestrial carbon budget.

Acknowledgements. This work was largely supported by the Australian Climate Change Science Program. We acknowledge the TRENDY and Transcom modellers for making their results available. We thank the Global Carbon Project for the invitation to participate in RECCAP and Eva van Gorsel for her contribution via the CSIRO internal review process.

Edited by: P. Ciais

\section{References}

ABARES: Energy in Australia 2011, ABARES (Australian Bureau of Agricultural and Resource Economics and Sciences), Commonwealth of Australia, Canberra, 2011.

Andres, R. J., Boden, T. A., Bréon, F.-M., Ciais, P., Davis, S., Erickson, D., Gregg, J. S., Jacobson, A., Marland, G., Miller, J., Oda, T., Olivier, J. G. J., Raupach, M. R., Rayner, P., and Treanton, K.: A synthesis of carbon dioxide emissions from fossil-fuel combustion, Biogeosciences, 9, 1845-1871, doi:10.5194/bg-9-18452012, 2012.

Australian Greenhouse Office: National greenhouse gas inventory 2004, Australian Government Department of the Environment and Heritage, 2006.

Australian Surface Water Management Areas (ASWMA) 2000: Product User Guide, 3rd Edn., Geoscience Australia, Canberra, 2004.

Barrett, D. J.: Timescales and Dynamics of Carbon in Australia's Savannas, in: Ecosystem Function in Savannas: Measurement and Modeling at Landscape to Global Scales, edited by: Hill, M. J. and Hanan, N. P., CRC Press, 347-366, 2010.

Bass, A. M., Bird, M. I., Liddell, M. J., and Nelson, P. N.: Fluvial dynamics of dissolved and particulate organic carbon during periodic discharge events in a steep tropical rainforest catchment, Limnol. Oceanogr., 56, 2282-2292, 2011.

Boden, T. A., Andres, R. J., and Marland, G.: Global, regional and national fossil-fuel $\mathrm{CO}_{2}$ emissions, Carbon Dioxide Information Analysis Center, Oak Ridge National Laboratory, US Department of Energy, Oak Ridge, TN, USA, doi:10.3334/CDIAC/00001_V2012, 2012.

Boon, K. F., Kiefert, L., and McTainsh, G. H.: Organic matter content of rural dusts in Australia, Atmos. Environ., 32, 2817-2823, 1998.

Canadell, J. G., Le Quere, C., Raupach, M. R., Field, C. B., Buitenhuis, E. T., Ciais, P., Conway, T. J., Gillett, N. P., Houghton, R. A., and Marland, G.: Contributions to accelerating atmospheric $\mathrm{CO}_{2}$ growth from economic activity, carbon intensity, and efficiency of natural sinks, P. Natl. Acad. Sci. USA, 104, 1886618870, 2007.

Canadell, J. G., Ciais, P., Gurney, K., Le Quere, C., Piao, S., Raupach, M. R., and Sabine, C. L.: An international effort to quantify regional carbon fluxes, EOS, 92, 81-82, 2011.

Craig, R., Heath, B., Raisbeck-Brown, N., Steber, M., J., M., and Smith, R.: The distribution, extent and seasonality of large fires in Australia, April 1998-March 2000, as mapped from NOAA-
AVHRR imagery, in: Australian fire regimes: contemporary patterns (April 1998-March 2000) and changes since European settlement, Department of the Environment and Heritage, Canberra, 2002.

Cramer, W., Bondeau, A., Woodward, F. I., Prentice, I. C., Betts, R. A., Brovkin, V., Cox, P. M., Fisher, V., Foley, J. A., Friend, A. D., Kucharik, C., Lomas, M. R., Ramankutty, N., Sitch, S., Smith, B., White, A., and Young-Molling, C.: Global response of terrestrial ecosystem structure and function to $\mathrm{CO}_{2}$ and climate change: results from six dynamic global vegetation models, Global Change Biol., 7, 357-373, 2001.

CSIRO: Water availability in the Murray-Darling Basin: a report to the Australian Government from the CSIRO Murray-Darling Basin Sustainable Yields Project, CSIRO, Canberra, Australia, 2008.

Davis, S. J. and Caldeira, K.: Consumption-based accounting of $\mathrm{CO}_{2}$ emissions, P. Natl. Acad. Sci., 107, 5687-5692, 2010.

DCCEE: Australia's national greenhouse accounts: quarterly update of Australia's National Greenhouse Gas Inventory (December Quarter 2011), Department of Climate Change and Energy Efficiency, Australian Government, Canberra, 2012.

Donohue, R. J., McVicar, T. R., and Roderick, M. L.: Climaterelated trends in Australian vegetation cover as inferred from satellite observations, 1981-2006, Global Change Biol., 15, 1025-1039, 2009.

Furnas, M. J.: Catchments and Corals: Terrestrial Runoff to the Great Barrier Reef, Australian Institute of Marine Science and CRC Reef Research Centre, 2003.

Giglio, L., Randerson, J. T., van der Werf, G. R., Kasibhatla, P. S., Collatz, G. J., Morton, D. C., and DeFries, R. S.: Assessing variability and long-term trends in burned area by merging multiple satellite fire products, Biogeosciences, 7, 1171-1186, doi:10.5194/bg-7-1171-2010, 2010.

Ginoux, P., Prospero, J. M., Torres, O., and Chin, M.: Long-term simulation of global dust distribution with the GOCART model: correlation with North Atlantic Oscillation, Environ. Modell. Software, 19, 113-128, 2004.

Glazebrook, H. S. and Robertson, A. I.: The effect of flooding and flood timing on leaf litter breakdown rates and nutrient dynamics in a river red gum (Eucalyptus camaldulensis) forest, Aust. J. Ecol., 24, 625-635, 1999.

Graetz, R. D.: The net carbon dioxide flux from biomass burning on the Australian continent, CSIRO Division of Atmospheric Research, 2002.

Grant, I., Jones, D., Wang, W., Fawcett, R., and Barratt, D.: Meteorological and remotely sensed datasets for hydrological modelling: A contribution to the Australian Water Availability Project, Catchment-scale Hydrological Modelling and Data Assimilation (CAHMDA-3) International Workshop on Hydrological Prediction: Modelling, Observation and Data Assimilation, Melbourne, 2008.

Hattersley, P. W.: The distribution of $c_{3}$-grass and $c_{4}$-grasses in australia in relation to climate, Oecologia, 57, 113-128, 1983.

Haverd, V. and Cuntz, M.: Soil-Litter-Iso: A one-dimensional model for coupled transport of heat, water and stable isotopes in soil with a litter layer and root extraction, J. Hydrol., 388, 438455, 2010.

Haverd, V., Raupach, M. R., Briggs, P. R., Canadell, J. G., Isaac, P., Pickett-Heaps, C., Roxburgh, S. H., van Gorsel, E., Viscarra 
Rossel, R. A., and Wang, Z.: Multiple observation types reduce uncertainty in Australia's terrestrial carbon and water cycles, Biogeosciences Discuss., 9, 12181-12258, doi:10.5194/bgd-912181-2012, 2012.

Hladyz, S., Watkins, S. C., Whitworth, K. L., and Baldwin, D. S.: Flows and hypoxic blackwater events in managed ephemeral river channels, J. Hydrol., 401, 117-125, 2011.

Houldcroft, C. J., Grey, W. M. F., Barnsley, M., Taylor, C. M., Los, S. O., and North, P. R. J.: New Vegetation Albedo Parameters and Global Fields of Soil Background Albedo Derived from MODIS for Use in a Climate Model, J. Hydrometeorol., 10, 183-198, 2009.

Hutchinson, M. F., Nix, H. A., and McMahon, J. P.: Climate constraints on cropping systems, in: Field Crop Systems, edited by: Pearson, C. J., Elsevier, Amsterdam, 37-58, 1992.

Hutchinson, M. F., McIntyre, S., Hobbs, R. J., Stein, J. L., Garnett, S., and Kinloch, J.: Integrating a global agro-climatic classification with bioregional boundaries in Australia, Global Ecol. Biogeogr., 14, 197-212, 2005.

Ito, A.: A historical meta-analysis of global terrestrial net primary productivity: are estimates converging?, Global Change Biol., 17, 3161-3175, 2011.

Jones, D. A., Wang, W., and Fawcett, R.: High-quality spatial climate data-sets for Australia, Aust. Meteorol. Oceanogr. J., 58, 233-248, 2009.

Keeling, C. D., Piper, S. C., Bacastow, R. B., Wahlen, M., Whorf, T. P., Heimann, M., and Meijer, H. A.: Exchanges of atmospheric $\mathrm{CO}_{2}$ and $13 \mathrm{CO}_{2}$ with the terrestrial biosphere and oceans from 1978 to 2000, I. Global aspects, Scripps Institution of Oceanography, San Diego, 2001.

King, E. A., Paget, M. J., Briggs, P. R., Trudinger, C. M., and Raupach, M. R.: Operational Delivery of Hydro-Meteorological Monitoring and Modeling Over the Australian Continent, Ieee J. Sel. Top. Appl., 2, 241-249, 2009.

Krausmann, F., Erb, K. H., Gingrich, S., Lauk, C., and Haberl, H.: Global patterns of socioeconomic biomass flows in the year 2000: A comprehensive assessment of supply, consumption and constraints, Ecol. Econ., 65, 471-487, 2008.

Le Quere, C., Raupach, M. R., Canadell, J. G., Marland, G., Bopp, L., Ciais, P., Conway, T. J., Doney, S. C., Feely, R. A., Foster, P., Friedlingstein, P., Gurney, K. R., Houghton, R. A., House, J. I., Huntingford, C., Levy, P. E., Lomas, M. R., Majkut, J., Metzl, N., Ometto, J., Peters, G. P., Prentice, I. C., Randerson, J. T., Running, S. W., Sarmiento, J. L., Schuster, U., Sitch, S., Takahashi, T., Viovy, N., van der Werf, G. R., and Woodward, F. I.: Trends in the sources and sinks of carbon dioxide, Nature Geosci., 2, 831-836, doi:10.1038/NGEO689, 2009.

Li, F., Ginoux, P., and Ramaswamy, V.: Distribution, transport, and deposition of mineral dust in the Southern Ocean and Antarctica: Contribution of major sources, J. Geophys. Res.-Atmos., 113, D10207, doi:10.1029/2007JD009190 2008.

Lu, H., Raupach, M. R., McVicar, T. R., and Barrett, D. J.: Decomposition of vegetation cover into woody and herbaceous components using AVHRR NDVI time series, Remote Sens. Environ., $86,1-18,2003$.

Luo, C., Mahowald, N. M., and del Corral, J.: Sensitivity study of meteorological parameters on mineral aerosol mobilization, transport, and distribution, J. Geophys. Res.-Atmos., 108, 4447, doi:10.1029/2003JD003483, 2003.
Luo, C., Mahowald, N., Bond, T., Chuang, P. Y., Artaxo, P., Siefert, R., Chen, Y., and Schauer, J.: Combustion iron distribution and deposition, Global Biogeochem. Cy., 22, GB1012, doi:10.1029/2007GB002964, 2008.

MacFarling Meure, C. M., Etheridge, D., Trudinger, C., Steele, P., Langenfelds, R., van Ommen, T., Smith, A., and Elkins, J.: Law Dome $\mathrm{CO}_{2}, \mathrm{CH}_{2}$ and $\mathrm{N}_{2} \mathrm{O}$ ice core records extended to 2000 years BP, Geophys. Res. Lett., 33, L14810, doi:10.1029/2006GL026152, 2006.

Maher, B. A., Prospero, J. M., Mackie, D., Gaiero, D., Hesse, P. P., and Balkanski, Y.: Global connections between aeolian dust, climate and ocean biogeochemistry at the present day and at the last glacial maximum, Earth-Sci. Rev., 99, 61-97, 2010.

Marland, G. and Rotty, R. M.: Carbon dioxide emissions from fossil fuels: A procedure for estimation and results for 1950-1982, Tellus B, 36, 232-261, 1984.

Meybeck, M., Durr, H. H., and Vorosmarty, C. J.: Global coastal segmentation and its river catchment contributors: A new look at land-ocean linkage, Global Biogeochem. Cy., 20, GB1S90, doi:10.1029/2005GB002540, 2006.

Meyer, C. P.: Establishing a consistent time-series of greenhouse gas emission estimates from Savanna burning in Australia, Report to the Australian Greenhouse Office by CSIRO Atmospheric Research, Aspendale, Australia, 2004.

Miller, R. L., Tegen, I., and Perlwitz, J.: Surface radiative forcing by soil dust aerosols and the hydrologic cycle, J. Geophys. Res.Atmos., 109, D04203, doi:10.1029/2003JD004085, 2004.

Montreal Process Implementation Group for Australia: Australia's State of the Forests Report 2008, Bureau of Rural Sciences, Canberra, 2008.

Pan, Y. D., Birdsey, R. A., Fang, J. Y., Houghton, R., Kauppi, P. E., Kurz, W. A., Phillips, O. L., Shvidenko, A., Lewis, S. L., Canadell, J. G., Ciais, P., Jackson, R. B., Pacala, S. W., McGuire, A. D., Piao, S. L., Rautiainen, A., Sitch, S., and Hayes, D.: A Large and Persistent Carbon Sink in the World's Forests, Science, 333, 988-993, 2011.

Peters, G. P.: From production-based to consumption-based national emission inventories, Ecol. Econom., 65, 13-23, 2008.

Peters, G. P., Minx, J. C., Weber, C. L., and Edenhofer, O.: Growth in emission transfers via international trade from 1990 to 2008 , P. Natl. Acad. Sci. USA, 108, 8903-8908, 2011.

Peters, G. P., Davis, S. J., and Andrew, R.: A synthesis of carbon in international trade, Biogeosciences, 9, 3247-3276, doi:10.5194/bg-9-3247-2012, 2012.

Randerson, J. T., Thompson, M. V., Conway, T. J., Fung, I. Y., and Field, C. B.: The contribution of terrestrial sources and sinks to trends in the seasonal cycle of atmospheric carbon dioxide, Global Biogeochem. Cy., 11, 535-560, 1997.

Raupach., M. R. R., Briggs, P. R., Haverd, V., King, E. A., Paget, M., and Trudinger, C. M.: Australian Water Availability Project (AWAP): CSIRO Marine and Atmospheric Research Component: Final Report for Phase 3, Canberra, 2009.

Richards, G. P. and Brack, C. L.: A continental biomass stock and stock exchange estimation approach for Australia, Austral. For., 67, 284-288, 2004.

Richards, G. and Evans, D.: Development of a carbon accounting model (FullCAM Vers. 1.0) for the Australian continent, Aust. Forestry, 67, 277-283, 2004. 
Richards, G. P., Borough, C., Evans, D., Reddin, A., Ximenes, F., and Gardner, D.: Developing a carbon stocks and flows model for Australian wood products, Austral. For., 70, 108-119, 2007.

Sieler, W. and Crutzen, P. J.: Estimates of gross and net fluxes of carbon between the biosphere and the atmosphere from biomass burning, Clim. Change, 2, 207-247, 1980.

Sitch, S. A. and Friedlingstein, P.: GCP-Land trends: modelling protocol, University of Exeter, available at: http://dgvm.ceh.ac.uk/ system/files/Trendy_protocol20_Nov2011_0.pdf (last access: 25 January 2013), 2011.

Tanaka, T. Y. and Chiba, M.: A numerical study of the contributions of dust source regions to the global dust budget, Global Planet. Change, 52, 88-104, 2006.

UNFCCC: On-line searchable database of greenhouse gas inventory data, version 1.4, available at: http://ghg.unfccc.int/ (last access: 25 January 2013), 2011.

van der Werf, G. R., Randerson, J. T., Giglio, L., Collatz, G. J., Mu, M., Kasibhatla, P. S., Morton, D. C., DeFries, R. S., Jin, Y., and van Leeuwen, T. T.: Global fire emissions and the contribution of deforestation, savanna, forest, agricultural, and peat fires (19972009), Atmos. Chem. Phys., 10, 11707-11735, doi:10.5194/acp10-11707-2010, 2010.

Vink, S., Bormans, M., Ford, P. W., and Grigg, N. J.: Quantifying ecosystem metabolism in the middle reaches of Murrumbidgee River during irrigation flow releases, Mar. Freshwater Res., 56, 227-241, 2005.

Wang, Y. P., Law, R. M., and Pak, B.: A global model of carbon, nitrogen and phosphorus cycles for the terrestrial biosphere, Biogeosciences, 7, 2261-2282, doi:10.5194/bg-7-2261-2010, 2010.
Wang, Y. P., Kowalczyk, E., Leuning, R., Abramowitz, G., Raupach, M. R., Pak, B., van Gorsel, E., and Luhar, A.: Diagnosing errors in a land surface model (CABLE) in the time and frequency domains, J. Geophys. Res.-Biogeosci., 116, G01034, doi:10.1029/2010JG001385, 2011.

Waterworth, R. M. and Richards, G. P.: Implementing Australian forest management practices into a full carbon accounting model, Forest Ecol. Manage., 255, 2434-2443, 2008.

Waterworth, R. M., Richards, G. P., Brack, C. L., and Evans, D. M. W.: A generalised hybrid process-empirical model for predicting plantation forest growth, Forest Ecol. Manage., 238, 231-243, 2007.

Webb, N. P., Chappell, A., Strong, C. L., Marx, S. K., and McTainsh, G. H.: The significance of carbon-enriched dust for global carbon accounting, Global Change Biol., 18, 3275-3278, doi:10.1111/j.1365-2486.2012.02780.x, 2012.

Werner, M., Tegen, I., Harrison, S. P., Kohfeld, K. E., Prentice, I. C., Balkanski, Y., Rodhe, H., and Roelandt, C.: Seasonal and interannual variability of the mineral dust cycle under present and glacial climate conditions, J. Geophys. Res.-Atmos., 107, 4744, doi:10.1029/2002JD002365, 2002.

Yue, X., Wang, H. J., Wang, Z. F., and Fan, K.: Simulation of dust aerosol radiative feedback using the Global Transport Model of Dust: 1, Dust cycle and validation, J. Geophys. Res.-Atmos., 114, D10202, doi:10.1029/2008JD010995, 2009.

Zender, C. S., Bian, H. S., and Newman, D.: Mineral Dust Entrainment and Deposition (DEAD) model: Description and 1990's dust climatology, J. Geophys. Res.-Atmos., 108, 4416, doi:10.1029/2002JD002775, 2003. 